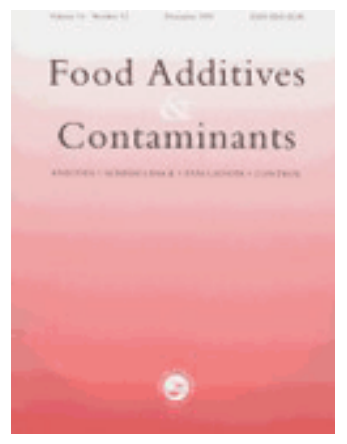

\title{
Simultaneous determination of type A, B, and D trichothecenes and their occurrence in cereals and cereal products
}

\begin{tabular}{|c|c|}
\hline Journal: & Food Additives and Contaminants \\
\hline Manuscript ID: & TFAC-2008-327.R1 \\
\hline Manuscript Type: & Original Research Paper \\
\hline $\begin{array}{r}\text { Date Submitted by the } \\
\text { Author: }\end{array}$ & 09-Apr-2009 \\
\hline Complete List of Authors: & $\begin{array}{l}\text { Gottschalk, Christoph; Technische Universität München, Institute of } \\
\text { Animal Hygiene } \\
\text { Barthel, Jörg; Bavarian Health and Food Safety Authority, } \\
\text { Oberschleißheim } \\
\text { Engelhardt, Gabriele; Bavarian Health and Food Safety Authority, } \\
\text { Oberschleißheim } \\
\text { Bauer, Johann; Technische Universität München, Institute of Animal } \\
\text { Hygiene } \\
\text { Meyer, Karsten; Technische Universität München, Institute of } \\
\text { Animal Hygiene }\end{array}$ \\
\hline Methods/Techniques: & Chromatography - LC/MS \\
\hline Additives/Contaminants: & trichothecenes \\
\hline Food Types: & Cereals and grain \\
\hline
\end{tabular}

\section{SCHOLARONE \\ Manuscripts}




\title{
Simultaneous determination of type A, B, and D trichothecenes and their occurrence in cereals and cereal products
}

\author{
Christoph Gottschalk ${ }^{1}$, Jörg Barthel ${ }^{2}$, Gabriele Engelhardt ${ }^{2}$, Johann Bauer ${ }^{1}$, Karsten Meyer $^{1}$ \\ ${ }^{1}$ Technische Universitaet Muenchen, Institute of Animal Hygiene, Weihenstephaner Berg 3, \\ 85354 Freising, Germany; ${ }^{2}$ Bavarian Health and Food Safety Authority, Veterinärstraße 2, \\ 85764 Oberschleißheim, Germany
}

Running title: Determination of type A, B and D trichothecenes by LC-MS/MS

Corresponding author: Christoph Gottschalk, Technische Universitaet Muenchen, Institute of Animal Hygiene, Weihenstephaner Berg 3, 85354 Freising, Germany. Tel. +49-8161-715503, Fax +49-8161-714516; e-mail: christoph.gottschalk@wzw.tum.de

\begin{abstract}
Abbreviations: 3-acDON, 3-acetyl-deoxynivalenol; 15-acDON, 15-acetyl-deoxynivalenol; C13-DON, ${ }^{13} \mathrm{C}_{15}$-deoxynivalenol; C13-T-2, ${ }^{13} \mathrm{C}_{24}$-T-2 toxin; DAS, 4,15-diacetoxyscirpenol; DacVOL, 4,15-diacetylverrucarol; DON, deoxynivalenol; EC, European Commission; FX, fusarenon-X; LOD, limit of detection; LOQ, limit of quantification; MAS, 15monoacetoxyscirpenol; NEO, neosolaniol; NIV, nivalenol; RA, roridin A; SG, satratoxin G; $\mathrm{SH}$, satratoxin $\mathrm{H}$; TDI, tolerable daily intake; VA, verrucarin A; VOL, verrucarol
\end{abstract}




\begin{abstract}
A sensitive LC-MS/MS method for the simultaneous determination of type A, B, and D trichothecenes in cereals is presented. The limits of detection ranged between $0.1 \mu \mathrm{g} \mathrm{kg}^{-1}$ and $0.7 \mu \mathrm{g} \mathrm{kg}^{-1}$ for all analytes. The method was applied to 289 representatively drawn samples of wheat, rye, and oat products. Ninety-four percent of the wheat samples $(n=130), 95 \%$ of the rye samples $(n=61)$, and $100 \%$ of the oat samples $(n=98)$ were contaminated with the type A trichothecenes T-2 and HT-2 toxin. Median levels of T-2/HT-2 (sum of the toxins) were $0.91 \mu \mathrm{g} \mathrm{kg}^{-1}, 0.53 \mu \mathrm{g} \mathrm{kg}^{-1}$, and $8.2 \mu \mathrm{g} \mathrm{kg}^{-1}$, respectively. Highest levels were found in wheat bran $\left(24 \mu \mathrm{g} \mathrm{kg}^{-1}\right)$, rye kernels $\left(3.1 \mu \mathrm{g} \mathrm{kg}^{-1}\right)$, and oat flakes $\left(85 \mu \mathrm{g} \mathrm{kg}^{-1}\right)$. All wheat and rye samples and $75 \%$ of the oat samples were contaminated with the type B trichothecene deoxynivalenol. Median levels of this toxin were $23 \mu \mathrm{g} \mathrm{kg}^{-1}, 15 \mu \mathrm{g} \mathrm{kg}^{-1}$, and $0.53 \mu \mathrm{g} \mathrm{kg}^{-1}$, respectively. Highest levels were found in wheat bran $\left(1160 \mu \mathrm{g} \mathrm{kg}^{-1}\right)$, rye kernels $\left(288 \mu \mathrm{g} \mathrm{kg}^{-1}\right)$, and oat flakes $\left(55 \mu \mathrm{g} \mathrm{kg}^{-1}\right)$. The type B trichothecene nivalenol was detected in $67 \%$ of the wheat samples, in $3 \%$ of the rye samples, and in $24 \%$ of the oat samples with highest levels in wheat bran $\left(96 \mu \mathrm{g} \mathrm{kg}^{-1}\right)$, rye kernels $\left(1.8 \mu \mathrm{g} \mathrm{kg}^{-1}\right)$, and in oat flakes $\left(17 \mu \mathrm{g} \mathrm{kg}^{-1}\right)$, respectively. Levels of other type A and B trichothecenes played a minor role, although the rates of contamination were often high. Neither macrocyclic type D trichothecenes (satratoxin G and H, verrucarin A, roridin A) nor the type A trichothecenes diacetylverrucarol and verrucarol were detected in any of the samples.
\end{abstract}

Keywords: mycotoxin / trichothecenes / cereals / deoxynivalenol / T-2 toxin / satratoxin 


\section{Introduction}

Three to four hundered secondary fungal metabolites have been recognized as mycotoxins (Bennett et al. 2003). Of these almost 150 belong to the large group of trichothecenes. These are cyclic sesquiterpenoids characterized by a 12,13-epoxide ring (WHO 1990). Trichothecenes are generally known as cytotoxic and immunosuppressive mycotoxins. They are mainly produced by certain species of Fusarium, as well as by species of the genera Myrothecium, Stachybotrys, Trichothecium, and Trichoderma. Trichothecenes are divided into four groups according to their chemical structures (Ueno 1983a). Type A trichothecenes are characterized by an oxygen function different from a carbonyl group at the C-8 position while type B trichothecenes possess a carbonyl function at this position. Type $\mathrm{C}$ trichothecenes have a second epoxide group at $\mathrm{C}$ 7,8 or C-9,10 whereas type D trichothecenes contain a macrocyclic ring between C-4 and C-15 (Figure 1). F. sporotrichioides and F. langsethiae are the main producers of type A trichothecenes like T-2 and HT-2 toxin in European cereals (Torp et al. 2004, Thrane et al. 2004). Oats and maize are considered to be most contaminated with this group of trichothecenes. Type B trichothecenes like deoxynivalenol (DON) are primarily produced by $F$. graminearum and F. culmorum which play a major role in maize, wheat and rye (SCOOP 2003). Various multi-methods for the determination of these toxins in cereals have been developed in the past few years (Lagana et al. 2003, Berthiller et al. 2005, Biselli et al. 2005, Klötzel et al. 2005). The macrocyclic type D trichothecenes are metabolites of Myrothecium spp. (e.g. roridin A, verrucarin A) and Stachybotrys spp. (e.g. satratoxin G and H; Ueno 1983a). While type A and B trichothecenes are commonly known as contaminants of food and feed, it is assumed that macrocyclic trichothecenes rarely occur in these matrices (WHO 1990, Krska et al. 2001). However, these toxins have occasionally been determined in hay or straw and were identified as causative agents of stachybotryotoxicosis (Jarvis et al. 1986), a severe disease that primarily affects horses. During the last years, macrocyclic trichothecenes have attracted more attention as indoor pollutants. They are suspected to be responsible for several adverse health effects in humans living or working in Stachybotrys-affected environments (Johanning et al. 1996, Jarvis et al. 1998, Gottschalk et al. 2008). Regarding food, there are only a few studies 
focussing on these analytes. In 1980, Stack and Eppley first described a method for cereal grains with LODs between 100 and $200 \mu \mathrm{g} \mathrm{kg}^{-1}$, but no naturally contaminated samples were analyzed (Stack and Eppley 1980). Recently published and more sensitive methods for type A, B and D trichothecenes in foodstuffs (Gentili et al. 2007, Stecher et al. 2007) comprised no satratoxins. Furthermore, only a very small number of samples was analyzed.

Maximum levels for trichothecenes in cereals and corn currently only exist for DON (Commission Regulation (EC) No 1881/2006 and No 1126/2007). According to mean intake data provided by a study from the Scientific Cooperation, the dietary exposure to T-2 and HT-2 may be critical. Especially in the group of infants and children the temporary tolerable daily intake (tTDI) for the sum of these toxins could be exceeded by more than fivefold (SCOOP 2003). The EC thus requested more occurrence data of these toxins in order to establish an appropriate maximum level (Commission Regulation (EC) No 1881/2006).

A sensitive LC-MS/MS multi-trichothecene method was developed in this study. Data regarding the contamination rates and levels of type A, B and the (at least in food) hardly studied type D trichothecenes in representatively drawn wheat, rye and oat samples are presented. Furthermore, the levels of mycotoxin contamination are compared and evaluated with respect to the possible health risks for the consumer.

\section{Materials and methods}

Samples

Sampling was performed according to Commission Regulation (EC) No 401/2006. Samples (total $n=289)$ of wheat products $(n=130)$, rye products $(n=61)$, and oat products $(n=98)$ were collected from grain milling factories or from wholesale in Bavaria. Products under study included kernels, flour, semolina, bran, and flakes. A small number of these samples $(n=18)$ were oat- $(n=13)$ or wheat-containing $(n=5)$ infant food. All samples were of German origin from the crop years 2005 and 2006. The grain kernel samples were fully processed (including 
cleaning and dehulling steps), suitable for direct consumption. In addition to these food grain samples, 17 samples of oats of feed quality were included in this study.

\section{Chemicals and reagents}

Standards of the type A trichothecenes T-2 toxin, HT-2 toxin, 4,15-diacetoxyscirpenol, 15monoacetoxyscirpenol, T-2 triol, T-2 tetraol, neosolaniol, 4,15-diacetylverrucarol, and verrucarol, standards of the type B trichothecenes deoxynivalenol, nivalenol, fusarenon-X, 3and 15-acetyldeoxynivalenol as well as standards of the type D trichothecenes roridin A and verrucarin A were purchased from Sigma (Deisenhofen, Germany). 13C-stable isotope standards for DON and T-2 toxin were from Biopure (Coring System Diagnostix, Gernsheim, Germany). Acetonitrile for extraction (HPLC grade) was purchased from Riedel-de Haën (Deisenhofen, Germany). Methanol (Riedel-de Haën, Deisenhofen, Germany) and ammonium formate (Fluka, Deisenhofen, Germany) were used in LC-MS quality. Water was purified on a milli-Q water purification system (Millipore, Schwalbach, Germany).

Standards of the type D trichothecenes satratoxin $\mathrm{G}$ and $\mathrm{H}$ were produced in our laboratory. A toxigenic strain of Stachybotrys chartarum was cultivated on rice (Jarvis et al. 1986). After a period of eight weeks at room temperature, cultures were extracted with acetonitrile/water 84/16 (v/v) and the extracts were cleaned using MycoSep ${ }^{\circledR} \# 226$ columns. The purified extracts were fractionated by semi-preparative HPLC with MS/MS-detection using a T-fitting to collect the fractions. A Beckman ultrasphere column (ODS, $150 \times 4.6 \mathrm{~mm}, 5 \mu \mathrm{m})$ and a binary linear gradient of methanol (pump A) and deionized water (pump B) was used for separation of the toxins at a flow rate of $1000 \mu \mathrm{l} / \mathrm{min}: 0 \min 90 \% \mathrm{~B}, 40 \min 0 \% \mathrm{~B}, 41 \min 90 \% \mathrm{~B}, 45 \min 90 \%$ B. The injection volume was $200 \mu$ l. The fractions were evaporated to dryness using a gentle stream of nitrogen at $40{ }^{\circ} \mathrm{C}$. The crystalline residues were then dissolved and stored in acetonitrile. The standards were verified and quantified using reference substances which were kindly provided by Manfred Gareis (Max-Rubner Institute, Kulmbach, Germany). 


\section{Sample preparation}

The complete aggregate samples (between 1 and $10 \mathrm{~kg}$ ) were finely ground and homogenized before analysis. The sub-samples $(20 \mathrm{~g})$ were extracted with $80 \mathrm{ml}$ acetonitrile/water $84 / 16(\mathrm{v} / \mathrm{v})$ by blending at high speed (10000 rpm, $3 \mathrm{~min})$ with an Ultra Turrax homogenizer (IKALabortechnik, Staufen, Germany). For some infant food samples the double volume of extraction solvent was used because of their high swelling properties. The extracts were centrifuged $(6000 \mathrm{~g}, 10 \mathrm{~min})$ and aliquots of $8 \mathrm{ml}$ were purified with MycoSep ${ }^{\circledR}$ columns (\# 226, Coring System Diagnostix, Germany) according to the manufacturer's instructions. The MycoSep ${ }^{\circledR}$ method has successfully been applied by many other working groups (Berthiller et al. 2005, Biselli et al. 2005, Klötzel et al. 2005). As also observed by Stecher et al. (2007), the commonly used MycoSep ${ }^{\circledR}$ trichothecene column \#227 was not suited for type D trichothecenes. Their high charcoal content led to very low recoveries (data not shown). $4 \mathrm{ml}$ of the extracts were evaporated to dryness with a gentle stream of nitrogen at a temperature of $40{ }^{\circ} \mathrm{C}$ (Barkey, Leopoldshöhe, Germany). For LC-MS/MS analysis the residues were dissolved in $1 \mathrm{ml}$ of methanol/deionized water $5 / 95(\mathrm{v} / \mathrm{v})$ and were filtered through a $0.45 \mu \mathrm{m}$ PTFE syringe filter (Supelco, Deisenhofen, Germany).

\section{LC-MS/MS instrumentation and parameters}

LC-MS/MS analysis was performed with a high pressure gradient HPLC apparatus from Shimadzu (Duisburg, Germany) and a triple quadrupole mass spectrometer API 4000 from Applied Biosystems (Darmstadt, Germany). The LC system consisted of an autosampler (SIL HT-C), two pumps (LC-10ADVP), a degasser (DGU-14A), and a column oven (CTO10ACVP). A Synergi ${ }^{\mathrm{TM}}$ polar-RP ${ }^{\circledR}$ column, $150 \times 2 \mathrm{~mm}, 4 \mu \mathrm{m}$ (Phenomenex, Aschaffenburg, Germany) was used for the chromatographic separation of the analytes. The binary linear gradient consisted of eluent $\mathrm{A}$ (methanol $+5 \mathrm{mmol} / \mathrm{l}$ ammonium formate) and eluent $\mathrm{B}$ (deionized water) with a flow rate of $0.4 \mathrm{ml} / \mathrm{min}: 0 \min 95 \% \mathrm{~B}, 11 \min 95 \% \mathrm{~B}, 22 \min 35 \% \mathrm{~B}$, $26 \min 35 \% \mathrm{~B}, 27 \min 95 \% \mathrm{~B}, 35 \min 95 \% \mathrm{~B}$. It was not possible to analyze T-2 tetraol and NIV in a single run due to similar retention times and ionization with different polarities. T-2 
tetraol was determined in a second run with the following linear gradient: 0 min $70 \% \mathrm{~B}, 3 \mathrm{~min}$ $70 \%$

B, $5 \min 30 \%$

B, $11 \min 30 \%$

$\mathrm{B}, 11.5 \min 70 \%$

$\mathrm{B}, 13 \min 70 \%$

B. The column oven temperature was maintained at $40{ }^{\circ} \mathrm{C}$ and the injection volume was $20 \mu \mathrm{l}$.

MS experiments were carried out in positive and negative electrospray ionization (ESI) mode by separating the method in periods with the proper polarity (Figure 2). The source temperature was set at $500{ }^{\circ} \mathrm{C}$ and the nitrogen pressure of the nebulizer gas (GS1) was optimized at 55 psi. The collision gas (CAD-gas, nitrogen) was used in high mode $(\mathrm{CAD}=9)$. The pressure of the curtain gas for T-2 tetraol was set at $25 \mathrm{psi}$, the heating gas at $55 \mathrm{psi}$, and the ion spray voltage at $3000 \mathrm{~V}$. For the other toxins best sensitivity was achieved with 20 psi, 50 psi and $4500 \mathrm{~V}$, respectively. In positive ionization mode, all analytes were measured as adduct ions of ammonium $\left[\mathrm{M}+\mathrm{NH}_{4}\right]^{+}$. The toxins were identified in multiple reaction monitoring mode (MRM) by two specific fragment ions of one precursor ion according to Commission Decision 2002/657/EC. The MRM-transitions, de-clustering potentials (DP), collision energies (CE), cell exit potentials (CXP), and further parameters for each toxin are shown in Table 1 . The value of the entrance potential (EP) was $+10 \mathrm{~V}$ or $-10 \mathrm{~V}$ for all analytes depending on their ionization polarity.

\section{Method validation}

The method performance parameters were determined according to DIN 32645 (1994). The trichothecene stock solution was diluted into 25 concentrations between $250 \mathrm{ng} \mathrm{ml}^{-1}$ and $0.005 \mathrm{ng} \mathrm{ml}^{-1}$. These standard dilutions were measured to determine the linearity of the method, the correlation as well as the limits of detection (LODs) and of quantification (LOQs). The latter were also calculated using the signal-to-noise $(\mathrm{S} / \mathrm{N})$ approach $(\mathrm{S} / \mathrm{N}=3$ and $\mathrm{S} / \mathrm{N}=9$, respectively). The repeatability of the method was checked by five-fold measurements of the toxin standards at two concentrations $\left(1.0\right.$ and $\left.10 \mathrm{ng} \mathrm{ml}^{-1}\right)$. 
Recovery experiments were carried out after artificial contamination of homogenized, blank samples of wheat flour, rye flour, and ground oat flakes on three levels $\left(1.0 \mu \mathrm{g} \mathrm{kg}^{-1}, 10 \mu \mathrm{g} \mathrm{kg}^{-1}\right.$, and $50 \mu \mathrm{g} \mathrm{kg}^{-1}$ ) with five replicates each. The samples were fortified with a trichothecene standard mixture before extraction.

The accuracy of the method was checked by participation at an interlaboratory test for DON (DLA, Ahrensburg, Germany) and intra laboratory comparisons between the results of LCMS/MS and HPLC-FLD (post-column derivatization) measurements according to the method described by Engelhardt et al. (2006). Comparison measurements for T-2 and HT-2 in oat flakes were conducted with another laboratory.

\section{Mycotoxin quantification}

Quantification of most of the toxins was done by external calibration on five levels $(0,1.0,10$, 50, $200 \mathrm{ng} \mathrm{ml}^{-1}$ ). The ${ }^{13} \mathrm{C}$-stable isotope standards ${ }^{13} \mathrm{C}$-DON and ${ }^{13} \mathrm{C}-\mathrm{T}-2$ toxin were used for compensation of matrix suppression effects, which mainly occurred in wheat samples. After evaporation of the purified extracts, the residues were dissolved in eluent containing the ${ }^{13} \mathrm{C}$ standards at a concentration of $10 \mathrm{ng} \mathrm{ml}^{-1}$. To compensate for matrix effects which were also observed for NIV and T-2 tetraol, these two toxins were quantified by matrix assisted calibration. Therefore, extracts of blank wheat flour, rye flour, and ground oat flakes were used for the dilution of the toxin standards. Levels of toxins between the LOD and LOQ were calculated with half LOQ, at which the S/N-values were applied. All results were corrected by mean recovery rates for each toxin and matrix referring to the results of the recovery experiments.

\section{Results}

Method performance characteristics

According to DIN 32645 LODs/LOQs between $0.09 / 0.29 \mu \mathrm{g} \mathrm{kg}^{-1}$ for DAS and 0.70/2.2 $\mu \mathrm{g} \mathrm{kg}^{-1}$ for NIV were calculated. Using the signal-to-noise approach, these limits were mostly lower 
(Table 2). The repeatability ( $\mathrm{n}=5)$ as RSD was between $1.8 \%$ and $11 \%$ at a concentration of $1 \mathrm{ng} \mathrm{ml}^{-1}$. At a level of $10 \mathrm{ng} \mathrm{ml}^{-1}$, all RSDs were between $0.5 \%$ and $4.4 \%$. The method was linear between the LODs and $250 \mu \mathrm{g} \mathrm{kg}^{-1}$ except for HT-2, VOL, and SH (LOD - $200 \mu \mathrm{g} \mathrm{kg}^{-1}$ ) with correlation coefficients (linear regression) of $r>0.9980$ (Table 2).

The average recovery obtained with this method ranged between 60 and 108\% for all toxins and matrices with RSDs between $1.3 \%$ and $17 \%$. The lowest recoveries were observed for NIV and T-2 tetraol (Table 3). The accuracy of the method was confirmed by participation in an interlaboratory test for DON and comparison measurements for DON and T-2/HT-2. The results showed a satisfactory accordance (Table 4). Finally, the results of the validation measurements were considered to comply with the requirements of the EC (Commission Regulation (EC) No 401/2006).

\section{Trichothecene contamination of wheat samples}

The samples $(n=130)$ were analyzed for 18 type A, B and D trichothecenes. The levels of T2/HT-2 in all wheat samples ranged between LOD and $24 \mu \mathrm{g} \mathrm{kg}^{-1}$ with a contamination rate of $94 \%$ and a median contamination of $0.91 \mu \mathrm{g} \mathrm{kg}^{-1}$. The $95^{\text {th }}$ percentile value was $6.4 \mu \mathrm{g} \mathrm{kg}^{-1}$ (Table 5). Hereby, a correlation between T-2 and HT-2 levels was observed $\left(\mathrm{R}^{2}=0.7995\right)$. The levels of HT-2 were about sevenfold as high as those of T-2 (Figure 3). As compared in Figure 4, the highest levels were found in wheat bran. Levels of contamination of the other commodities of wheat are also listed in Table 5. T-2 tetraol occurred in 53\% of all samples with values between LOD and $83 \mu \mathrm{g} \mathrm{kg}^{-1}$ in a wheat bran sample. The median level, however, was only $0.15 \mu \mathrm{g} \mathrm{kg}^{-1}$. Other type A trichothecenes like T-2 triol, NEO and DAS were detected with lower frequency and in smaller amounts (Table 5). The rate of contamination with MAS was $92 \%$ but the levels were consistently low (median $0.11 \mu \mathrm{g} \mathrm{kg}^{-1}$, maximum value $5.9 \mu \mathrm{g} \mathrm{kg}^{-1}$ in wheat bran). VOL and DacVOL were not detected above their LODs. 
All wheat samples were contaminated with DON between 0.06 and $1160 \mu \mathrm{g} \mathrm{kg}^{-1}$. The median contamination was $23 \mu \mathrm{g} \mathrm{kg}^{-1}$ with a $95^{\text {th }}$ percentile value of $162 \mu \mathrm{g} \mathrm{kg}^{-1}$ (Table 5). Again, the highest value was found in bran (Figure 4). However, this was the only sample to exceed the maximum level set by the EC (Commission Regulation No 1881/2006). Sixty-seven percent of the samples were contaminated with NIV at a median level of $1.8 \mu \mathrm{g} \mathrm{kg}^{-1}$ and a maximum level of $96 \mu \mathrm{g} \mathrm{kg}^{-1}$ in wheat bran. The 3- and 15-acetyl metabolites of DON were detected in 52 and $72 \%$ of all wheat samples with median values of only $0.21 \mu \mathrm{g} \mathrm{kg}^{-1}$ and $0.17 \mu \mathrm{g} \mathrm{kg}^{-1}$, respectively. The highest levels of $15 \mu \mathrm{g} \mathrm{kg}^{-1}$ and $26 \mu \mathrm{g} \mathrm{kg}^{-1}$ were also found in wheat bran (Table 5). 15-acDON-levels were about $2 \%$ of the DON-levels (Figure 3). No type D trichothecenes were detected above their LODs between $0.02 \mu \mathrm{g} \mathrm{kg}^{-1}$ for RA and $0.15 \mu \mathrm{g} \mathrm{kg}^{-1}$ for SH.

\section{Trichothecene contamination of rye samples}

Rye samples $(n=61)$ were less contaminated with trichothecenes, even though the rates of contamination hardly differed from those of wheat. The median level of T-2/HT-2 in all rye samples was $0.53 \mu \mathrm{g} \mathrm{kg}^{-1}$ with a the $95^{\text {th }}$ percentile value of $1.8 \mu \mathrm{g} \mathrm{kg}$. The rate of contamination was $95 \%$ (Table 6) and a maximum level of $3.1 \mu \mathrm{g} \mathrm{kg}^{-1}$ was measured in rye flour (Figure 4). Higher levels (median $2.0 \mu \mathrm{g} \mathrm{kg}^{-1}$ and $95^{\text {th }}$ percentile value $6.4 \mu \mathrm{g} \mathrm{kg}^{-1}$ ) were observed for T-2 tetraol with a rate of contamination of $79 \%$ and a maximum level of $8.1 \mu \mathrm{g} \mathrm{kg}$ ${ }^{1}$ in rye kernels (Table 6). DAS, VOL and DacVOL were not detected and the levels of MAS and NEO were very low. Due to the low T-2 and HT-2 levels, the correlation between these two toxins was less evident than in wheat or oats (Figure 3).

However, all samples were contaminated with DON. The median contamination with this toxin was $15 \mu \mathrm{g} \mathrm{kg}^{-1}$ and the $95^{\text {th }}$ percentile value was $92 \mu \mathrm{g} \mathrm{kg}^{-1}$. The highest value of $288 \mu \mathrm{g} \mathrm{kg}^{-1}$ was found in rye kernels (Table 6). 3-acDON and 15-acDON were detected with mean levels of lower than $1 \mu \mathrm{g} \mathrm{kg}^{-1}$ in $59 \%$ and $80 \%$ of the samples. It could be observed that the amounts of 
DON were about 30 times as high as the levels of 15-acDON (Figure 3). NIV and FX levels were almost all below the LOD. No type D trichothecenes were detected.

\section{Trichothecene contamination of oat samples}

All oat samples $(\mathrm{n}=98)$ were contaminated with T-2/HT-2 between 0.04 and $85 \mu \mathrm{gg}^{-1}$ (Table 7). The median and $95^{\text {th }}$ percentile value were $8.2 \mu \mathrm{g} \mathrm{kg}^{-1}$ and $50 \mu \mathrm{g} \mathrm{kg}{ }^{-1}$. The highest levels were measured in fine oat flakes (Figure 4). All five samples (5.1\%) which exceeded a level of $50 \mu \mathrm{g} \mathrm{kg}^{-1}$ for the sum of T-2/HT-2 were part of this commodity. The T-2 levels in oats were about half the levels of HT-2 (Figure 3). Within the group of type A trichothecenes, T-2 tetraol also played a major role (rate of contamination 90\%). The median level was $6.4 \mu \mathrm{g} \mathrm{kg}^{-1}$ (95 ${ }^{\text {th }}$ percentile value: $\left.25 \mu \mathrm{g} \mathrm{kg}^{-1}\right)$. The highest value of $85 \mu \mathrm{g} \mathrm{kg}^{-1}$ was measured in a baby food sample (Table 7). For T-2 triol, NEO, DAS, and MAS, levels of at most $2.7 \mu \mathrm{g} \mathrm{kg}^{-1}$ were determined. VOL and DacVOL were not detected in any sample.

The contamination rate of DON was $74 \%$ of all oat samples. The median value was $0.53 \mu \mathrm{g} \mathrm{kg}^{-1}$ and the $95^{\text {th }}$ percentile $11 \mu \mathrm{g} \mathrm{kg}^{-1}$. A maximum value of $55 \mu \mathrm{g} \mathrm{kg}^{-1}$ was determined in fine oat flakes (Table 7). DON-levels of different commodities of oats are compared in Figure 4. 3acDON and 15 -acDON were measured each with a rate of contamination of $28 \%$ in all oat samples and with maximum levels of $8.2 \mu \mathrm{g} \mathrm{kg}^{-1}$ and $1.4 \mu \mathrm{g} \mathrm{kg}^{-1}$. These levels were too low to observe a good correlation with DON (Figure 3). NIV occurred in $24 \%$ of the oat samples with a maximum level of $17 \mu \mathrm{g} \mathrm{kg}^{-1}$ found in fine oat flakes (Table 7). The highest contamination with FX (6.1\% positive samples) was below $1.0 \mu \mathrm{g} \mathrm{kg}^{-1}$. Again, no type D trichothecenes were detected.

\section{Trichothecene contamination of infant food}

In $100 \%$ of the oat-containing baby food samples $(n=13)$ and in $80 \%$ of the wheat-containing samples (n=5) T-2/HT-2 was detected. The median values were $6.0 \mu \mathrm{g} \mathrm{kg}^{-1}$ and $0.36 \mu \mathrm{g} \mathrm{kg}^{-1}$, respectively (Figure 4). The highest value of $23 \mu \mathrm{g} \mathrm{kg}^{-1}$ was found in an oat porridge powder 
which was concurrently contaminated with $85 \mu \mathrm{g} \mathrm{kg}{ }^{-1} \mathrm{~T}-2$ tetraol (Table 7). Otherwise, the levels of T-2 tetraol were low just like those of the other analytes. In Figure 4, also the DON levels of oat and wheat-containing infant food were compared to the other food commodities. DON was detected in $54 \%$ and $100 \%$ of these samples with median values of $0.17 \mu \mathrm{g} \mathrm{kg}^{-1}$ and $9.9 \mu \mathrm{g} \mathrm{kg}^{-1}$ (Table 5). The highest level of $24 \mu \mathrm{g} \mathrm{kg}^{-1}$ was detected in a semolina powder (Table 5). 3-acDON and 15-acDON were detected with levels below $3.2 \mu \mathrm{g} \mathrm{kg}^{-1}$. Three samples contained NIV with maximal $8.8 \mu \mathrm{g} \mathrm{kg}^{-1}$ (Table 5) and only one sample FX $\left(0.18 \mu \mathrm{g} \mathrm{kg}^{-1}\right.$, Table 7).

\section{Trichothecene contamination of feed oats}

Oats of feed quality $(n=17)$ were contaminated at a much higher level with type A and B trichothecenes due to the fact that the samples were husked oat kernels. The toxin levels are usually reduced about $90 \%$ by de-husking the grains (Scudamore et al. 2007). Maximum values of $531 \mu \mathrm{g} \mathrm{kg}^{-1} \mathrm{~T}-2 / \mathrm{HT}-2$ and $654 \mu \mathrm{g} \mathrm{kg}^{-1} \mathrm{~T}-2$ tetraol in the same sample were measured. The median $/ 95^{\text {th }}$ percentile values were $162 \mu \mathrm{g} \mathrm{kg} / 356 \mu \mathrm{g} \mathrm{kg}^{-1}$ and $146 \mu \mathrm{g} \mathrm{kg} \mathrm{g}^{-1} / 331 \mu \mathrm{g} \mathrm{kg}^{-1}$, respectively (rates of contamination 100\%). T-2 tetraol again contributed considerably to the total type A trichothecene burden. All samples contained DAS (median/95 ${ }^{\text {th }}$ percentile value: $\left.0.61 \mu \mathrm{g} \mathrm{kg}^{-1} / 3.2 \mu \mathrm{g} \mathrm{kg}^{-1}\right)$, MAS $\left(1.6 \mu \mathrm{g} \mathrm{kg}^{-1} / 6.3 \mu \mathrm{g} \mathrm{kg}^{-1}\right)$, and NEO $\left(4.7 \mu \mathrm{g} \mathrm{kg}^{-1} / 17 \mu \mathrm{g} \mathrm{kg}^{-1}\right)$. For NEO, comparatively high values up to $28 \mu \mathrm{g} \mathrm{kg}^{-1}$ were determined. Thereby, a strong correlation was also observed between the levels of T-2 and NEO. In this matrix, the levels were high enough to not be influenced by the LOQ of the method. The NEO-level was about $15 \%$ of the one of T-2 $\left(\mathrm{R}^{2}=0.9496\right)$. No VOL or DacVOL were measured.

\footnotetext{
All samples were concurrently contaminated with DON (median/95 ${ }^{\text {th }}$ percentile value: $58 \mu \mathrm{g} \mathrm{kg}$ $\left.{ }^{1} / 678 \mu \mathrm{g} \mathrm{kg}^{-1}\right)$ and NIV $\left(57 \mu \mathrm{g} \mathrm{kg}^{-1} / 189 \mu \mathrm{g} \mathrm{kg}^{-1}\right)$. Two samples had exceptionally high levels of $2400 \mu \mathrm{g} \mathrm{kg}^{-1}$ and $490 \mu \mathrm{g} \mathrm{kg}^{-1}$, respectively. The contamination rates of 3-acDON, 15-acDON, and FX were $53 \%, 24 \%$, and $29 \%$, respectively. The levels of $3-\mathrm{acDON}$ (median/95 ${ }^{\text {th }}$ percentile value: $\left.0.76 \mu \mathrm{g} \mathrm{kg}^{-1} / 32 \mu \mathrm{g} \mathrm{kg}^{-1}\right), 15-\mathrm{acDON}\left(<\mathrm{LOD} / 3.8 \mu \mathrm{g} \mathrm{kg}^{-1}\right)$, and FX $\left(<\mathrm{LOD} / 3.4 \mu \mathrm{g} \mathrm{kg}^{-1}\right)$ were still low, although they remarkably differed from those of the food samples. Only the
} 
sample with the highest DON-contamination contained a mentionable amount of $99 \mu \mathrm{g} \mathrm{kg}^{-1}$ of 3-acDON. However, no type D trichothecenes were detected.

\section{Discussion}

\section{Type A trichothecenes}

Oats and oat products had the highest levels of contamination with type A trichothecenes (Table 7). However, the comparatively low contamination of wheat should not be disregarded because of its much higher intake. In SCOOP task 3.2.10 (2003), wheat was identified as the predominant source of T-2/HT-2, but also of DON and NIV intake. As reported in the SCOOP study, oat samples were most frequently contaminated with HT-2 (rate of contamination 41\%), followed by maize $(24 \%)$, rye $(17 \%)$, and wheat $(12 \%)$. The highest contamination rate with T$2(28 \%)$ was found in maize (oats $16 \%$, wheat and rye $21 \%$, each). In this project, however, $100 \%$ of the oat samples, $94 \%$ of the wheat samples and $95 \%$ of the rye samples contained $\mathrm{T}$ 2/HT-2, which can be traced back to the much lower detection limits of this method. Thus, also the rates of contamination of T-2 triol, DAS, MAS, and NEO were much higher (Tables 5-7) in this study. However, the concentrations of these analytes were all below the LODs of the methods applied in the SCOOP study (2003), where only $1 \%$ to $6 \%$ of the samples were positive for these analytes. The LODs for type A trichothecenes in wheat, rye or oats were between 2 and $20 \mu \mathrm{g} \mathrm{kg}^{-1}$ in dependence of the analyte and the contributing laboratory. Like in this study, VOL was not detected, but no samples were analyzed for T-2 tetraol or DacVOL. However, data on the occurrence of T-2 tetraol were provided by Klötzel et al. (2005) and Schollenberger et al. (2006). Both reported high levels of this analyte in oats which were even higher than T-2 or HT-2, also supporting our results.

In comparison to the concentrations of type A trichothecenes found in this study, the levels reported in SCOOP (2003) were much higher. T-2 levels of wheat were between 2 and $160 \mu \mathrm{g}$ $\mathrm{kg}^{-1}$, HT-2 levels between 3 and $50 \mu \mathrm{g} \mathrm{kg}^{-1}$. In rye, T-2 values ranged between 10 and $190 \mu \mathrm{g}$ $\mathrm{kg}^{-1}$. HT-2 values of between 10 and $70 \mu \mathrm{g} \mathrm{kg}$ were determined. T-2 levels in oats ranged 
between 10 and $550 \mu \mathrm{g} \mathrm{kg}^{-1}$ and HT-2 levels between 10 and $1150 \mu \mathrm{g} \mathrm{kg}^{-1}$ (SCOOP 2003). The values of the few T-2 triol, DAS, MAS, and NEO-positive samples were between 30 and $50 \mu \mathrm{g}$ $\mathrm{kg}^{-1}$. These higher levels may be a result of differing origins or crop years. It also has to be considered that the samples analyzed here were all at least cleaned and de-hulled cereals intended for human consumption. It has been shown that raw cereal kernels contain a tenfold higher toxin amount than de-hulled kernels (Scudamore et al. 2007). Furthermore, Northern European countries contributed results to the SCOOP study where usually the highest T-2/HT-2 levels are determined (Langseth et al. 1999, Pettersson et al. 2006).

The correlations between T-2 and HT-2 in the different cereal types gave interesting results. While in wheat the level of HT-2 was about sevenfold as high as the T-2 level, HT-2 levels in oats were only about twice as high as those of T-2. The contamination levels of rye were however too low to be able to make proper comparisons (Figure 3). These different levels may be due to the ability of the plant to metabolize T-2 to HT-2 which has been described for species of Baccharis (Mirocha et al. 1988). The synthesis of deacetylases may be plant-specific. In this context, also deacetylases originating from bacteria of the plant can play a role in metabolizing processes (Beeton et al. 1989, Ueno et al. 1983b). Differences in the correlations between T-2 and HT-2 levels may be due to differing bacterial flora of each plant. However, it is questionable whether these processes could lead to such considerable correlations. It seems more likely that the different cereal types are infected by different Fusarium species or strains which possess characteristic metabolite production abilities.

Anyway, oat products had the highest levels of contamination with T-2/HT-2 as well as T-2 tetraol. It should be noticed that the predominantly consumed oat products, fine oat flakes, were the food commodity with the highest levels (Figure 4). Especially infants and children have a high intake of these products by the consumption of muesli (see also "dietary intake estimation"). This should be of concern to official food control authorities and for future legislation. 


\section{Type B trichothecenes}

All wheat and rye samples were contaminated with DON, while $74 \%$ of the oat samples contained this analyte. The mean contamination level of rye $\left(28 \mu \mathrm{g} \mathrm{kg}^{-1}\right)$ was about half the level of wheat $\left(57 \mu \mathrm{g} \mathrm{kg}^{-1}\right)$ while the mean DON-burden of oats was comparably low $(2.8 \mu \mathrm{g}$ $\mathrm{kg}^{-1}$; Tables 5-7). In the SCOOP study (2003), DON was detected in only $61 \%$ of the wheat samples (mean level of all contributing countries: $205 \mu \mathrm{g} \mathrm{kg}^{-1}$ ), in $41 \%$ of the rye samples $\left(42 \mu \mathrm{g} \mathrm{kg}^{-1}\right)$, and in $33 \%$ of the oat samples $\left(95 \mu \mathrm{g} \mathrm{kg}^{-1}\right)$. The rates of contamination as well as the toxin levels were influenced by the LODs of the different methods applied in the SCOOP study (2.0 to $220 \mu \mathrm{g} \mathrm{kg}^{-1}$ ). In wheat the levels of DON ranged between 2.0 and $50000 \mu \mathrm{g} \mathrm{kg}^{-1}$, between 2.0 and $595 \mu \mathrm{g} \mathrm{kg}^{-1}$ in rye, and between 2.0 and $5004 \mu \mathrm{g} \mathrm{kg}^{-1}$ in oats. Engelhardt et al. (2006) reported mean DON levels in wheat of $138 \mu \mathrm{g} \mathrm{kg}^{-1}$. Mean levels in wheat and oats reported by Biselli et al. (2005) were 230 and $250 \mu \mathrm{g} \mathrm{kg}^{-1}$. Similar results were shown by Schollenberger et al. (2002). The levels found in this study were much lower, which may be a result of the same reasons discussed above (Scudamore et al. 2007).

In the SCOOP study (2003), only $8.0 \%$ of the wheat samples, less than $1.0 \%$ of the rye samples and $6.0 \%$ of the oat samples contained 3 -acDON, but at least $20 \%$ of all samples 15 -acDON. Much higher rates of contamination were determined in this study (Tables 5-7). It was shown that the levels of the acetyl metabolites of DON were only about 2 to $3 \%$ as high as the DONlevels of wheat and rye. Due to the low DON-levels in oats, no correlation could be observed in this matrix (Figure 3). Basically, the 15-acDON levels were higher than those of 3-acDON. This resulted in more positive samples which exceeded the LOD. These results are in accordance with Klötzel et al. (2005).

For NIV, rates of contamination of $14 \%$ of wheat (values between 2.0 and $440 \mu \mathrm{g} \mathrm{kg}^{-1}$ ), $5.0 \%$ of rye (values between 2.0 and $48 \mu \mathrm{g} \mathrm{kg}^{-1}$ ), and $21 \%$ of oats (values between 2.0 and $1860 \mu \mathrm{g} \mathrm{kg}^{-1}$ ) were reported in SCOOP data (2003). In spite of the more sensitive method applied here, the 
contamination rates of rye and oats from SCOOP data were similar to our results (Tables 5-7). However, $67 \%$ of the wheat samples were found to be NIV-positive, but with much lower contamination levels as a result of the above mentioned reasons.

The rates and levels of contamination with FX were extremely low in this study (Tables 5-7). Schollenberger et al. $(1999,2002)$ and Klötzel et al. (2005) also reported no positive cerealbased food samples, wheat or oat samples (LODs: $6 \mu \mathrm{g} \mathrm{kg}^{-1}$ and $1.3 \mu \mathrm{g} \mathrm{kg}^{-1}$ ). However, $10 \%$ of the wheat samples from SCOOP contained FX between $3.3 \mu \mathrm{g} \mathrm{kg}^{-1}$ and $50 \mu \mathrm{g} \mathrm{kg}^{-1}$.

\section{Type D trichothecenes}

To our knowledge, this was the first measurement of type D trichothecenes in a multitude of representative cereal food samples $(\mathrm{n}=289)$ since 1980 , when a much less sensitive method was applied (Stack and Eppley 1980). Thus it was necessary to develop a sensitive LC-MS/MS method to provide more up-to-date occurrence data. No samples contained satratoxin G or $\mathrm{H}$, roridin A or verrucarin A above their LODs. Actually, it can be concluded that Stachybotrys spp. and Myrothecium spp. metabolites did not represent a risk to food security, at least as regarding wheat, rye and oat products. The number of horse feed samples (raw oats, $n=17$ ) was too low to draw proper conclusions, but no sample contained macrocyclic trichothecenes. However, results of Kluwe revealed that stachybotryotoxicosis still is a risk in horse feeding. At least $20 \%$ of 100 hay and straw samples contained Stachybotrys spp. Altogether, 32 strains have been isolated and were tested for their toxinogenicity. More than $35 \%$ of these strains possessed the tri5-gene and actually produced satratoxin $\mathrm{G}$ and $\mathrm{H}$ as examined by LC-MS/MS (Kluwe 2006).

\section{Estimation of dietary intake}

The toxicity of DON, NIV, and T-2/HT-2 was evaluated by the Scientific Committee on Food (SCF) in a set of opinions (SCF 1999-2002). In a group evaluation of these four analytes, the Committee concluded that combined or synergistic effects were not probable, although currently 
available data on this matter was limited. Hence, the Committee confirmed the single TDIvalues or temporary TDI-values (t-TDI) for each toxin as follows:

- $\quad$ DON: TDI $=1 \mu \mathrm{g} \mathrm{kg}^{-1}$ body weight (bw)/day

- $\quad$ NIV: $\mathrm{t}-\mathrm{TDI}=0.7 \mu \mathrm{g} \mathrm{kg}^{-1}$ bw/day

- $\quad$ T-2/HT-2: $\mathrm{t}-\mathrm{TDI}=0.06 \mu \mathrm{g} \mathrm{kg}{ }^{-1}$ bw/day

In the following, intake estimations for DON, NIV and T-2/HT-2 were conducted for young children and infants. These are the consumer groups with the highest risk, as they have an exceptionally high intake in relation to their body weight. Hereby, data on the average consumption of wheat flour, rye flour, oat flakes, and oat-containing baby food were used (Table 8). The average body weight of nine-month-old infants and two- to five-year-old children were quoted with $8.95 \mathrm{~kg}$ and $16.15 \mathrm{~kg}$ (Kersting et al. 1998, Banasiak et al. 2005). The calculations were conducted for a mean case scenario (average consumption $\times$ median toxin concentration) and a bad case scenario (average consumption $\times 95^{\text {th }}$ percentile value of toxin concentration). The corresponding levels of contamination can be gleaned from Tables 5-7.

The daily toxin intake by average consumption of selected food commodities and the percentage of the corresponding TDI-values is shown in Table 8. In the SCOOP study (2003) wheat was identified as the major source of T-2/HT-2 as well as DON and NIV intake. As expected, this was re-confirmed at least with regard to DON and NIV. However, the consumption of oat flakes was shown to play a major role in T-2/HT-2 exposure in this study. The contribution of rye, however, seemed to be negligible. Assuming the mean case scenario, the total T-2/HT-2 intake by the daily ingestion of wheat and rye flour as well as oat flakes barely corresponded to $10 \%$ of the t-TDI, whereas the intake by baby food was more than $30 \%$ of the t-TDI (Table 8 ). It must be pointed out that the number of baby food samples examined in this study was too small to justify proper conclusions. However, the T-2/HT-2 levels of oat-containing baby food (n=13) indicated a possible exceedance of the t-TDI in the sub-population of infants giving cause for 
further study. Furthermore, it should be mentioned that not only T-2/HT-2 primarily accounted for the total type A trichothecene burden but also T-2 tetraol, although this analyte possesses a lower toxicity.

The intake of DON mostly depended on the consumption of wheat. In spite of its high consumption, the contribution to the TDI was only $10 \%$ assuming the median contamination level. In the bad case scenario, the DON intake amounted to $44 \%$ of the TDI (Table 8 ). The total DON intake by the daily consumed wheat, rye and oat commodities was slightly increased by the contamination of rye flour, while oat flakes as a source for DON-intake were negligible. The contamination of baby food was considerably lower, which resulted in a very low exposure even assuming the bad case scenario.

The exposure to NIV played a minor role after consumption of the cereals examined in this study. Even in the worse-case scenario only about 7\% of the t-TDI for NIV were reached. Rye, oats, and baby food did not or hardly contributed to a NIV-exposure (Table 8).

In conclusion, the risk of exceeding the TDI-values could be regarded as low with respect to average consumption and toxin concentrations, in comparison with data of the SCOOP-report (2003). Therein, the percentage of the TDI by the DON-intake of infants ranged between $11 \%$ and $96 \%$ and between $27 \%$ and $560 \%$ for the T-2/HT-2 intake, subject to the calculations of the contributing countries. However, infants represented the sub-population with the highest risk to exceed the t-TDI of T-2/HT-2 also in this study. Thus, the setting of a maximum level may be appropriate particularly for baby food or special commodities like oat flakes. It should be noted that wheat, for example, did not contain only DON but also T-2/HT-2 and that the simultaneous occurrence of these toxins leads to a higher total mycotoxin ingestion. Hence, the consideration of a group-TDI for trichothecenes may be useful for a proper risk assessment (Pronk et al. 2002). 
1

2

3

4

5

6

7

8

9

10

11

12

\section{Acknowledgements}

The authors want to thank the Bavarian State Ministry of the Environment, Public Health and Consumer Protection as well as the H. Wilhelm Schaumann foundation for the financial support. Also thanks to the teams of the mycotoxin laboratories for their unhesitant help and labor in grinding, homogenization and preparation of the samples and to Stefan Asam and Michael Rychlik for conducting comparison measurements. 


\section{References}

Banasiak U, Heseker H, Sieke C, Sommerfeld C, Vohmann C. 2005. Abschätzung der Aufnahme von Pflanzenschutzmittel-Rückständen in der Nahrung mit neuen Verzehrsmengen für Kinder. Bundesgesundheitsbl - Gesundheitsforsch - Gesundheitsschutz 48:84-98.

Beeton S, Bull AT. 1989. Biotransformation and Detoxification of T-2 Toxin by Soil and Freshwater Bacteria. Appl Environ Microbiol. 55:190-197.

Bennett JW, Klich M. 2003. Mycotoxins. Clin Microbiol Rev. 16:497-516.

Berthiller F, Schuhmacher R, Buttinger G, Krska R. 2005. Rapid simultaneous determination of major type A- and B-trichothecenes as well as zearalenone in maize by high performance liquid chromatography-tandem mass spectrometry. J Chrom A. 1062:209-216.

Biselli S, Hummert C. 2005. Development of a multicomponent method for Fusarium toxins using LC-MS/MS and its application during a survey for the content of T-2 toxin and deoxynivalenol in various feed and food samples. Food Add Contam. 22:752-760.

Deutsches Institut für Normung. 1994. DIN 32645 „Chemische Analytik; Nachweis-, Erfassungs- und Bestimmungsgrenze; Ermittlung unter Wiederholbedingungen; Begriffe, Verfahren, Auswertung“. Berlin, Germany.

Engelhardt G, Barthel J, Sparrer D. 2004. Fusarium mycotoxins and ochratoxin A in cereals and cereal products: results from the Bavarian Health and Food Safety Authority in 2004. Mol Nutr Food Res. 50:401-405. 
European Commission. Directorate-General Health and Consumer Protection. 1999-2002.

Scientific Committee on Food (SCF): Opinions of the SCF on Fusarium Toxins, Part 1-6. Available from: http://ec.europa.eu/food/food/chemicalsafety/contaminants/fusarium_en.htm

European Commission. Directorate-General Health and Consumer Protection. 2003. Scientific Cooperation: SCOOP Task 3.2.10: Collection of occurrence data of Fusarium toxins in food and assessment of dietary intake by population of EU Member States. Available from: http://ec.europa.eu/food/fs/scoop/task3210.pdf

European Commission. 2002. Commission Decision (EC) No 657/2002 of 12 August 2002 implementing Council Directive 96/23/EC concerning the performance of analytical methods and the interpretation of results. Off J Eur Union. L221:8-36.

European Commission. 2006. Commission Regulation (EC) No 401/2006 of 23 February 2006 laying down the methods of sampling and analysis for the official control of the levels of mycotoxins in foodstuffs. Off J Eur Union. L70:12-34.

European Commission. 2006. Commission Regulation (EC) No 1881/2006 of 19 December 2006 setting maximum levels for certain contaminants in foodstuffs. Off J Eur Union. L364,524.

European Commission. 2007. Commission Regulation (EC) No 1126/2007 of 28 September 2007 amending Regulation (EC) No 1881/2006 setting maximum levels for certain contaminants in foodstuffs as regards Fusarium toxins in maize and maize products. Off J Eur Union. L255:14-17. 
Gentili A, Caretti F, D’Ascenzo G, Mainero Rocca L, Marchese S, Materazzi S, Perret D. 2007. Simultaneous Determination of Trichothecenes A, B, and D in Maize Food Products by LCMS-MS. Chromatographia 66:669-676.

Gottschalk C, Bauer J, Meyer K. 2008. Detection of satratoxin G and H in indoor air from a water-damaged building. Mycopathologia 166:103-107.

Jarvis BB, Lee Y-W, Comezoglu SN, Yatawara CS. 1986. Trichothecenes produced by Stachybotrys atra from Eastern Europe. Appl Environ Microbiol. 51:915-918.

Jarvis BB, Sorenson WG, Hintikka EL, Nikulin M, Zhou Y, Jiang J, Wang S, Hinkley S, Etzel RA, Dearborn D. 1998. Study of toxin production by isolates of Stachybotrys chartarum and Memnoniella echinata isolated during a study of pulmonary hemosiderosis in infants. Appl Environ Microbiol. 64:3620-3625.

Johanning E, Biagini R, Hull D, Morey P, Jarvis B, Landsbergis P. 1996. Health and immunology study following exposure to toxigenic fungi (Stachybotrys chartarum) in a waterdamaged office environment. Int Arch Occup Environ Health 68:207-218.

Kersting M, Alexy U, Sichert-Hellert W, Manz F, Schöch G. 1998. Measured consumption of commercial infant food products in German infants: results from the DONALD study. J Pediatr Gastroenterol Nutr. 27:547-552.

Klötzel M, Gutsche B, Lauber U, Humpf H-U. 2005. Determination of 12 type A and B trichothecenes in cereals by liquid chromatography-electrospray tandem mass spectrometry. J Agric Food Chem. 53:8904-8910. 
Kluwe H. 2006. Untersuchungen zum Vorkommen und zur Toxizität von Stachybotrys spp. in Heu- und Strohproben aus Pferdeställen [dissertation]. [Munich, Germany]: LudwigMaximilians-Universität München.

Krska R, Baumgartner S, Josephs R. 2001. The state-of-the-art in the analysis of type-A and -B trichothecene mycotoxins in cereals. Fresenius J Anal Chem. 371:285-299.

Lagana A, Curini R, D’Ascenzo G, De Leva I, Faberi A, Pastorini E. 2003. Liquid chromatography/tandem mass spectrometry for the identification and determination of trichothecenes in maize. Rap Commun Mass Spec. 17:1037-1043.

Langseth W, Rundberget T. 1999. The occurrence of HT-2 toxin and other trichothecenes in Norwegian cereals. Mycopathologia. 147:157-165.

Mirocha CJ, Abbas HK, Treeful L, Bean G. 1988. T-2 Toxin and Diacetoxyscirpenol Metabolism by Baccharis spp. Appl Environ Microbiol. 54:2277-2280.

Pettersson H, Börjesson T. 2006. T-2 and HT-2 Toxins in Oats. Presented at: MycotoxinWorkshop. Proceedings of the $28^{\text {th }}$ Mycotoxin Workshop. May 29-31, Bydgoszcz, Poland.

Pronk MEJ, Schothorst RC, Egmond HP. 2002. Toxicology and occurrence of nivalenol, fusarenon X, diacetoxyscirpenol, neosolaniol and 3- and 15-acetyldeoxynivalenol: a review of six trichothecenes (Report No 388802024/2002). National Institute of Public Health and the Environment, Bilthoven, The Netherlands.

Schollenberger M, Suchy S, Jara HT, Drochner W, Müller H-M. 1999. A survey of Fusarium toxins in cereal-based foods marketed in an area of southwest Germany. Mycopathologia $147: 49-57$ 
Schollenberger M, Jara HT, Suchy S, Drochner W, Müller H-M. 2002. Fusarium toxins in wheat flour collected in an area in southwest Germany. Int J Food Microbiol. 72:85-89.

Schollenberger M, Müller H-M, Rüfle M, Suchy S, Plank S, Drochner W. 2006. Natural occurrence of 16 Fusarium toxins in grains and feedstuffs of plant origin from Germany. Mycopathologia 161: 43-52.

Scudamore KA, Baillie H, Patel S, Edwards SG. 2007. Occurrence and fate of Fusarium mycotoxins during commercial processing of oats in the UK. Food Add Contam. 24:1374-1385.

Stack ME, Eppley RM. 1980. High Pressure Chromatographic Determination of Satratoxins G and $\mathrm{H}$ in Cereal Grains. J Assoc Off Anal Chem. 63:1278-1281.

Stecher G, Jarukamjorn K, Zaborski P, Bakry R, Huck CW, Bonn GK. 2007. Evaluation of extraction methods for the simultaneous analysis of simple and macrocyclic trichothecenes. Talanta 73:251-257.

Thrane U, Adler A, Clasen P-E, Galvano F, Langseth W, Lew H, Logrieco A, Nielsen KF, Ritieni A. 2004. Diversity in metabolite production by Fusarium langsethiae, Fusarium poae, and Fusarium sporotrichioides. Int J Food Microbiol. 95:257-266.

Torp M, Nirenberg HI. 2004. Fusarium langsethiae sp. nov. on cereals in Europe. Int J Food Microbiol. 95:247-256.

Ueno Y. 1983a. Trichothecenes - Chemical, Biological and Toxicological Aspects. Elsevier, Amsterdam, The Netherlands. 
Ueno Y, Nakayama K, Ishii K, Tashiro F, Minoda Y, Omori T, Komagata K. 1983b. Metabolism of T-2 Toxin in Curtobacterium sp. Strain 114-2. Appl Environ Microbiol. 46:120127.

World Health Organisation (WHO). 1990. Selected mycotoxins: Ochratoxins, Trichothecenes, Ergot. Environmental Health Criteria 105. Geneva, Switzerland. 
Table 1. MRM-transitions and MS parameters for type A, B, and D trichothecenes

\begin{tabular}{|c|c|c|c|c|c|c|c|c|c|}
\hline Analyte & $\begin{array}{c}\text { MW } \\
\text { (g/mol) }\end{array}$ & Precursor & ion & Product & ions & $\mathbf{D P}(\mathbf{V})$ & $\begin{array}{l}\text { CE } \\
(\mathrm{eV})\end{array}$ & $\begin{array}{l}\text { CXP } \\
(\mathbf{V})\end{array}$ & $\begin{array}{c}\text { Dwell } \\
\text { time } \\
\text { (msec) }\end{array}$ \\
\hline \multicolumn{10}{|c|}{ Type A trichothecenes } \\
\hline \multirow[t]{2}{*}{$\mathrm{T}-2$} & 466 & {$\left[\mathrm{M}+\mathrm{NH}_{4}\right]^{+}$} & 483.9 & Quantifier & 305.2 & 61 & 19 & 20 & 75 \\
\hline & & & & Qualifier & 215.2 & 61 & 25 & 14 & 75 \\
\hline \multirow[t]{2}{*}{ 13C-T-2 } & 490 & {$\left[\mathrm{M}+\mathrm{NH}_{4}\right]^{+}$} & 508.3 & Quantifier & 229.2 & 46 & 25 & 14 & 75 \\
\hline & & & & Qualifier & 322.2 & 46 & 19 & 20 & 75 \\
\hline \multirow[t]{2}{*}{ HT-2 } & 424 & {$\left[\mathrm{M}+\mathrm{NH}_{4}\right]^{+}$} & 442.4 & Quantifier & 263.2 & 51 & 17 & 16 & 75 \\
\hline & & & & Qualifier & 215.1 & 51 & 19 & 16 & 75 \\
\hline \multirow[t]{2}{*}{$\mathrm{T}-2$ triol } & 382 & {$\left[\mathrm{M}+\mathrm{NH}_{4}\right]^{+}$} & 400.4 & Quantifier & 281.2 & 36 & 17 & 20 & 75 \\
\hline & & & & Qualifier & 215.1 & 36 & 13 & 18 & 75 \\
\hline \multirow[t]{2}{*}{ T-2 tetraol } & 298 & {$\left[\mathrm{M}+\mathrm{NH}_{4}\right]^{+}$} & 316.2 & Quantifier & 215.2 & 36 & 13 & 20 & 150 \\
\hline & & & & Qualifier & 281.3 & 36 & 11 & 18 & 150 \\
\hline \multirow[t]{2}{*}{ DAS } & 366 & {$\left[\mathrm{M}+\mathrm{NH}_{4}\right]^{+}$} & 384.2 & Quantifier & 307.3 & 51 & 17 & 10 & 75 \\
\hline & & & & Qualifier & 247.1 & 51 & 19 & 24 & 75 \\
\hline \multirow[t]{2}{*}{ MAS } & 324 & {$\left[\mathrm{M}+\mathrm{NH}_{4}\right]^{+}$} & 342.2 & Quantifier & 265.1 & 41 & 13 & 16 & 125 \\
\hline & & & & Qualifier & 107.1 & 41 & 19 & 10 & 125 \\
\hline \multirow[t]{2}{*}{ NEO } & 382 & {$\left[\mathrm{M}+\mathrm{NH}_{4}\right]^{+}$} & 400.2 & Quantifier & 305.3 & 51 & 17 & 18 & 125 \\
\hline & & & & Qualifier & 245.1 & 51 & 25 & 16 & 125 \\
\hline \multirow[t]{2}{*}{ DacVOL } & 350 & {$\left[\mathrm{M}+\mathrm{NH}_{4}\right]^{+}$} & 368.3 & Quantifier & 291.2 & 51 & 13 & 20 & 75 \\
\hline & & & & Qualifier & 249.1 & 51 & 21 & 18 & 75 \\
\hline \multirow[t]{2}{*}{ VOL } & 266 & {$\left[\mathrm{M}+\mathrm{NH}_{4}\right]^{+}$} & 284.2 & Quantifier & 267.2 & 36 & 7 & 16 & 125 \\
\hline & & & & Qualifier & 249.3 & 36 & 11 & 24 & 125 \\
\hline \multicolumn{10}{|c|}{ Type B trichothecenes } \\
\hline \multirow[t]{2}{*}{ DON } & 296 & {$[\mathrm{M}-\mathrm{H}]^{-}$} & 294.9 & Quantifier & 265.0 & -45 & -16 & -15 & 150 \\
\hline & & & & Qualifier & 138.0 & -45 & -22 & -11 & 150 \\
\hline \multirow[t]{2}{*}{ 13C-DON } & 311 & {$[\mathrm{M}-\mathrm{H}]^{-}$} & 310.3 & Quantifier & 144.9 & -55 & -22 & -7 & 150 \\
\hline & & & & Qualifier & 279.0 & -55 & -16 & -13 & 150 \\
\hline \multirow[t]{2}{*}{ 3-acDON } & 338 & {$[\mathrm{M}+\mathrm{NH} 4]^{+}$} & 356.3 & Quantifier & 231.1 & 36 & 25 & 16 & 125 \\
\hline & & & & Qualifier & 203.0 & 36 & 21 & 22 & 125 \\
\hline \multirow[t]{2}{*}{15 -acDON } & 338 & {$[\mathrm{M}+\mathrm{NH} 4]^{+}$} & 356.1 & Quantifier & 321.1 & 46 & 19 & 28 & 125 \\
\hline & & & & Qualifier & 137.2 & 46 & 21 & 14 & 125 \\
\hline \multirow[t]{2}{*}{ NIV } & 312 & {$\left[\mathrm{M}+\mathrm{HCOO}^{-}\right.$} & 357.1 & Quantifier & 281.0 & -50 & -18 & -13 & 150 \\
\hline & & & & Qualifier & 202.8 & -50 & -24 & -11 & 150 \\
\hline \multirow[t]{2}{*}{ FX } & 354 & {$[\mathrm{M}+\mathrm{NH} 4]^{+}$} & 372.1 & Quantifier & 355.1 & 41 & 11 & 24 & 125 \\
\hline & & & & Qualifier & 247.2 & 41 & 19 & 16 & 125 \\
\hline
\end{tabular}




\begin{tabular}{|c|c|c|c|c|c|c|c|c|c|}
\hline Type & & & & & & & & & \\
\hline \multirow[t]{2}{*}{ SG } & 544 & {$[\mathrm{M}+\mathrm{NH} 4]^{+}$} & 562.3 & Quantifier & 231.2 & 51 & 23 & 16 & 75 \\
\hline & & & & Qualifier & 249.2 & 51 & 21 & 18 & 75 \\
\hline \multirow[t]{2}{*}{$\mathrm{SH}$} & 528 & {$[\mathrm{M}+\mathrm{NH} 4]^{+}$} & 546.5 & Quantifier & 529.2 & 36 & 21 & 20 & 75 \\
\hline & & & & Qualifier & 281.1 & 36 & 21 & 18 & 75 \\
\hline \multirow[t]{2}{*}{ RA } & 532 & {$[\mathrm{M}+\mathrm{NH} 4]^{+}$} & 550.5 & Quantifier & 249.2 & 56 & 23 & 18 & 175 \\
\hline & & & & Qualifier & 533.4 & 56 & 15 & 18 & 175 \\
\hline \multirow[t]{2}{*}{ VA } & 502 & {$[\mathrm{M}+\mathrm{NH} 4]^{+}$} & 520.4 & Quantifier & 249.1 & 51 & 23 & 18 & 175 \\
\hline & & & & Qualifier & 457.3 & 51 & 17 & 14 & 175 \\
\hline
\end{tabular}

19 
Table 2: Performance parameters of the LC-MS/MS-method

\begin{tabular}{|c|c|c|c|c|c|c|c|c|}
\hline \multirow[b]{2}{*}{ Analyte } & \multirow{2}{*}{$\begin{array}{l}\text { Linearity }^{*} \\
\left(\mathrm{ng} \mathrm{ml}^{-1}\right)\end{array}$} & \multirow{2}{*}{$\begin{array}{c}\text { Correlation } \mathrm{r} \\
\text { (calibration points) }\end{array}$} & \multirow{2}{*}{$\begin{array}{c}\mathrm{RSD}(\mathrm{n}=5) \\
1 \mathrm{ng} \mathrm{ml}^{-1}\end{array}$} & \multirow{2}{*}{$\begin{array}{l}\operatorname{RSD}(\mathrm{n}=5) \\
10 \mathrm{ng} \mathrm{ml}^{-1}\end{array}$} & \multicolumn{2}{|c|}{ DIN $32645^{* *}$} & \multicolumn{2}{|c|}{ Signal-to-noise ${ }^{* * *}$} \\
\hline & & & & & $\begin{array}{c}\text { LOD } \\
\left(\mathrm{ng} \mathrm{ml}^{-1}\right)\end{array}$ & $\begin{array}{c}\text { LOQ } \\
\left(\mathrm{ng} \mathrm{ml} \mathrm{m}^{-1}\right)\end{array}$ & $\begin{array}{c}\text { LOD } \\
\left(\mathrm{ng} \mathrm{ml} l^{-1}\right)\end{array}$ & $\begin{array}{c}\text { LOQ } \\
\left(\mathrm{ng} \mathrm{ml}^{-1}\right)\end{array}$ \\
\hline \multicolumn{9}{|c|}{ Type A trichothecenes } \\
\hline $\mathrm{T}-2$ & LOD -250 & $0.9998(15)$ & $1.8 \%$ & $2.2 \%$ & 0.20 & 0.66 & 0.026 & 0.078 \\
\hline HT-2 & LOD - 200 & $0.9995(16)$ & $3.3 \%$ & $1.6 \%$ & 0.32 & 1.1 & 0.061 & 0.18 \\
\hline $\mathrm{T}-2$ triol & LOD -250 & $0.9996(15)$ & $6.7 \%$ & $4.4 \%$ & 0.27 & 0.92 & 0.16 & 0.49 \\
\hline $\mathrm{T}-2$ tetraol & LOD -250 & $0.9992(14)$ & $6.5 \%$ & $2.9 \%$ & 0.41 & 1.4 & 0.10 & 0.30 \\
\hline DAS & LOD -250 & $0.9999(15)$ & $4.1 \%$ & $1.8 \%$ & 0.085 & 0.29 & 0.030 & 0.089 \\
\hline MAS & LOD -250 & $0.9999(16)$ & $2.2 \%$ & $1.3 \%$ & 0.085 & 0.29 & 0.012 & 0.035 \\
\hline NEO & LOD - 250 & $0.9999(16)$ & $3.8 \%$ & $0.5 \%$ & 0.11 & 0.35 & 0.029 & 0.087 \\
\hline DacVOL & LOD -250 & $0.9999(15)$ & $3.1 \%$ & $1.0 \%$ & 0.064 & 0.22 & 0.017 & 0.051 \\
\hline VOL & LOD - 200 & $0.9995(15)$ & $7.6 \%$ & $0.8 \%$ & 0.34 & 1.1 & 0.27 & 0.82 \\
\hline \multicolumn{9}{|c|}{ Type B trichothecenes } \\
\hline DON & LOD - 250 & $0.9999(16)$ & $2.8 \%$ & $1.4 \%$ & 0.092 & 0.31 & 0.038 & 0.11 \\
\hline 3-acDON & LOD - 250 & $0.9996(15)$ & $8.4 \%$ & $1.5 \%$ & 0.28 & 0.96 & 0.14 & 0.42 \\
\hline $15-a c D O N$ & LOD - 250 & $0.9999(16)$ & $4.7 \%$ & $2.3 \%$ & 0.14 & 0.46 & 0.033 & 0.10 \\
\hline NIV & LOD - 250 & $0.9980(10)$ & $11 \%$ & $1.1 \%$ & 0.70 & 2.2 & 1.2 & 3.6 \\
\hline FX & LOD - 250 & $0.9999(16)$ & $4.8 \%$ & $1.1 \%$ & 0.11 & 0.37 & 0.12 & 0.35 \\
\hline \multicolumn{9}{|c|}{ Type D trichothecenes } \\
\hline SG & LOD - 250 & $0.9993(15)$ & $5.3 \%$ & $1.4 \%$ & 0.28 & 0.95 & 0.038 & 0.11 \\
\hline SH & LOD - 200 & $0.9993(15)$ & $9.1 \%$ & $3.1 \%$ & 0.38 & 1.3 & 0.15 & 0.46 \\
\hline RA & LOD - 250 & $0.9995(15)$ & $3.9 \%$ & $1.7 \%$ & 0.22 & 0.74 & 0.021 & 0.063 \\
\hline VA & LOD - 250 & $0.9996(16)$ & $2.5 \%$ & $0.7 \%$ & 0.20 & 0.67 & 0.044 & 0.13 \\
\hline
\end{tabular}


Table 3: Average recovery rates of type A, B and D trichothecenes from wheat flour, rye flour, and oat flakes (fortification levels $1 \mu \mathrm{g} \mathrm{kg}^{-1}, 10 \mu \mathrm{g} \mathrm{kg}^{-1}, 50 \mu \mathrm{g} \mathrm{kg}^{-1} ; \mathrm{n}=5$ )

\begin{tabular}{|c|c|c|c|}
\hline \multirow[b]{2}{*}{ Analyte } & \multicolumn{3}{|c|}{ Average recovery rate $(\%) \pm \mathrm{RSD}(\%)$} \\
\hline & wheat flour & rye flour & oat flakes \\
\hline \multicolumn{4}{|c|}{ Type A trichothecenes } \\
\hline $\mathrm{T}-2$ & $108 \pm 2.8$ & $95 \pm 6.1$ & $103 \pm 2.7$ \\
\hline HT-2 & $98 \pm 4.9$ & $93 \pm 10$ & $102 \pm 3.4$ \\
\hline $\mathrm{T}-2$ triol & $97 \pm 5.0$ & $92 \pm 3.7$ & $99 \pm 4.8$ \\
\hline T-2 tetraol & $73 \pm 7.8$ & $75 \pm 8.4$ & $60 \pm 8.4$ \\
\hline DAS & $106 \pm 1.3$ & $101 \pm 3.6$ & $107 \pm 2.6$ \\
\hline MAS & $101 \pm 1.5$ & $85 \pm 5.4$ & $97 \pm 2.3$ \\
\hline NEO & $99 \pm 5.0$ & $90 \pm 6.8$ & $98 \pm 3.3$ \\
\hline DacVOL & $96 \pm 2.8$ & $86 \pm 3.6$ & $96 \pm 3.6$ \\
\hline VOL & $101 \pm 5.3$ & $83 \pm 8.7$ & $95 \pm 6.8$ \\
\hline \multicolumn{4}{|c|}{ Type B trichothecenes } \\
\hline DON & $92 \pm 17$ & $89 \pm 11$ & $98 \pm 4.5$ \\
\hline $3-\mathrm{acDON}$ & $104 \pm 5.0$ & $96 \pm 6.2$ & $99 \pm 4.6$ \\
\hline $15-\mathrm{acDON}$ & $98 \pm 6.0$ & $95 \pm 6.4$ & $102 \pm 3.8$ \\
\hline NIV & $61 \pm 16$ & $67 \pm 11$ & $67 \pm 8.7$ \\
\hline FX & $87 \pm 4.9$ & $84 \pm 9.5$ & $94 \pm 4.7$ \\
\hline \multicolumn{4}{|c|}{ Type D trichothecenes } \\
\hline SG & $91 \pm 4.8$ & $83 \pm 6.3$ & $98 \pm 6.1$ \\
\hline SH & $87 \pm 5.3$ & $85 \pm 5.8$ & $92 \pm 6.0$ \\
\hline RA & $107 \pm 4.2$ & $87 \pm 6.9$ & $89 \pm 12$ \\
\hline VA & $78 \pm 4.9$ & $76 \pm 5.3$ & $81 \pm 9.0$ \\
\hline
\end{tabular}


Table 4. Trueness assessment of the method by interlaboratory tests and comparison measurements for T-2, HT-2, and DON

\begin{tabular}{|c|c|c|c|c|c|}
\hline \multirow[b]{2}{*}{ Laboratory / method } & \multirow[b]{2}{*}{ Material } & \multirow[b]{2}{*}{ Analyte } & \multicolumn{3}{|c|}{ Results with this } \\
\hline & & & Results & $\begin{array}{l}\text { LC-MS/MS } \\
\text { method }\end{array}$ & Accuracy \\
\hline $\begin{array}{l}\text { - Interlaboratory test } \\
\text { (DLA Ahrensburg, Germany; }\end{array}$ & $\begin{array}{l}\text { Cereals for animal } \\
\text { feed (DLA-05/2007) }\end{array}$ & DON & $\begin{array}{l}257-555 \mu \mathrm{g} \mathrm{kg}^{-1} \\
\left(\mathrm{X}=405 \mu \mathrm{g} \mathrm{kg}^{-1}\right)\end{array}$ & $324 \mu \mathrm{g} \mathrm{kg}^{-1}$ & z-score $=-1.1$ \\
\hline - Comparison measurement & Oat flakes (1) & $\mathrm{T}-2$ & $20 \mu \mathrm{g} \mathrm{kg}^{-1}$ & $18 \mu \mathrm{g} \mathrm{kg}^{-1}$ & $90 \%$ \\
\hline $\begin{array}{l}\text { (Chair of Food Chemistry, } \\
\text { Technische Universitaet }\end{array}$ & & HT-2 & $50 \mu \mathrm{g} \mathrm{kg}^{-1}$ & $49 \mu \mathrm{g} \mathrm{kg}^{-1}$ & $98 \%$ \\
\hline Muenchen, Germany; stable & Oat flakes (2) & $\mathrm{T}-2$ & $20 \mu \mathrm{g} \mathrm{kg}^{-1}$ & $17 \mu \mathrm{g} \mathrm{kg}^{-1}$ & $85 \%$ \\
\hline $\begin{array}{l}\text { isotope dilution assay - LC- } \\
\text { MS/MS) }\end{array}$ & & HT-2 & $45 \mu \mathrm{g} \mathrm{kg}^{-1}$ & $44 \mu \mathrm{g} \mathrm{kg}^{-1}$ & $98 \%$ \\
\hline - Comparison measurement & Wheat flour & DON & $106 \mu \mathrm{g} \mathrm{kg}^{-1}$ & $113 \mu \mathrm{g} \mathrm{kg}^{-1}$ & $107 \%$ \\
\hline (Bavarian Health and Food & Whole wheat flour & DON & $130 \mu \mathrm{g} \mathrm{kg}^{-1}$ & $121 \mu \mathrm{g} \mathrm{kg}^{-1}$ & $93 \%$ \\
\hline Safety Authority, & Wheat kernels & DON & $158 \mu \mathrm{g} \mathrm{kg}^{-1}$ & $149 \mu \mathrm{g} \mathrm{kg}^{-1}$ & $94 \%$ \\
\hline Oberschleißheim, Germany; & Wheat bran (1) & DON & $294 \mu \mathrm{g} \mathrm{kg}^{-1}$ & $325 \mu \mathrm{g} \mathrm{kg}^{-1}$ & $111 \%$ \\
\hline HPLC-FLD) & Wheat bran (2) & DON & $1087 \mu \mathrm{g} \mathrm{kg}^{-1}$ & $1069 \mu \mathrm{g} \mathrm{kg}^{-1}$ & $98 \%$ \\
\hline
\end{tabular}


Table 5. Rates and levels of contamination of different commodities of wheat with the most relevant trichothecenes. All samples $(n=130)$, wheat flour $(n=39)$, whole wheat flour $(n=11)$, wheat kernels $(n=52)$, semolina $(n=13)$, wheat bran $(n=10)$, and wheat-containing infant food $(\mathrm{n}=5)$

\begin{tabular}{|c|c|c|c|c|c|c|}
\hline Analyte & Commodity & $\begin{array}{c}\text { Contamination } \\
\text { rate }(\%)\end{array}$ & $\operatorname{Mean}\left(\mu \mathrm{g} \mathrm{kg}^{-1}\right)$ & $\begin{array}{l}\text { Median } \\
\left(\mu \mathrm{g} \mathrm{kg}^{-1}\right)\end{array}$ & $\begin{array}{c}95^{\text {th }} \text { percentile } \\
\left(\mu \mathrm{g} \mathrm{kg}^{-1}\right)\end{array}$ & $\begin{array}{c}\text { Maximum } \\
\text { value }\left(\mu \mathrm{g} \mathrm{kg}^{-1}\right)\end{array}$ \\
\hline \multirow[t]{7}{*}{$\mathrm{T}-2$} & all wheat samples & 85 & 0.21 & 0.09 & 0.91 & 1.9 \\
\hline & wheat flour & 85 & 0.09 & 0.04 & 0.17 & 1.2 \\
\hline & whole wheat flour & 100 & 0.16 & 0.15 & 0.25 & 0.25 \\
\hline & wheat kernels & 94 & 0.27 & 0.17 & 0.76 & 1.1 \\
\hline & semolina & 39 & 0.02 & $<$ LOD & 0.06 & 0.08 \\
\hline & wheat bran & 100 & 0.84 & 0.60 & 1.8 & 1.9 \\
\hline & infant food & 40 & 0.04 & $<$ LOD & 0.13 & 0.15 \\
\hline \multirow[t]{7}{*}{ HT-2 } & all wheat samples & 94 & 1.6 & 0.84 & 5.6 & 22 \\
\hline & wheat flour & 97 & 0.65 & 0.32 & 0.92 & 11 \\
\hline & whole wheat flour & 100 & 1.4 & 1.6 & 2.1 & 2.2 \\
\hline & wheat kernels & 100 & 1.9 & 1.4 & 4.4 & 5.8 \\
\hline & semolina & 54 & 0.13 & 0.09 & 0.45 & 0.67 \\
\hline & wheat bran & 100 & 7.1 & 6.7 & 17 & 22 \\
\hline & infant food & 80 & 0.55 & 0.32 & 1.2 & 1.3 \\
\hline \multirow[t]{7}{*}{$\mathrm{T}-2+\mathrm{HT}-2$} & all wheat samples & 94 & 1.8 & 0.91 & 6.4 & 24 \\
\hline & wheat flour & 97 & 0.74 & 0.34 & 1.1 & 12 \\
\hline & whole wheat flour & 100 & 1.6 & 1.8 & 2.4 & 2.4 \\
\hline & wheat kernels & 100 & 2.2 & 1.9 & 5.2 & 6.8 \\
\hline & semolina & 54 & 0.15 & 0.09 & 0.50 & 0.74 \\
\hline & wheat bran & 100 & 7.9 & 7.6 & 19 & 24 \\
\hline & infant food & 80 & 0.59 & 0.36 & 1.3 & 1.3 \\
\hline \multirow[t]{7}{*}{$\mathrm{T}-2$ triol } & all wheat samples & 18 & 0.08 & $<\mathrm{LOD}$ & 0.25 & 1.4 \\
\hline & wheat flour & 2.6 & 0.03 & $<$ LOD & $<$ LOD & 1.4 \\
\hline & whole wheat flour & 9.1 & 0.02 & $<$ LOD & 0.12 & 0.25 \\
\hline & wheat kernels & 28 & 0.07 & $<$ LOD & 0.25 & 0.25 \\
\hline & semolina & n.d. & $<$ LOD & $<\mathrm{LOD}$ & $<$ LOD & $<$ LOD \\
\hline & wheat bran & 78 & 0.55 & 0.52 & 1.2 & 1.3 \\
\hline & infant food & n.d. & $<$ LOD & $<$ LOD & $<$ LOD & $<$ LOD \\
\hline \multirow[t]{3}{*}{$\mathrm{T}-2$ tetraol } & all wheat samples & 53 & 2.6 & 0.15 & 8.0 & 83 \\
\hline & wheat flour & 21 & 0.78 & $<$ LOD & 1.4 & 25 \\
\hline & whole wheat flour & 73 & 1.5 & 1.7 & 3.2 & 3.4 \\
\hline
\end{tabular}




\begin{tabular}{|c|c|c|c|c|c|c|}
\hline & wheat kernels & 79 & 2.7 & 1.8 & 8.0 & 10 \\
\hline & semolina & 7.7 & 0.04 & $<$ LOD & 0.19 & 0.46 \\
\hline & wheat bran & 100 & 17 & 4.2 & 65 & 83 \\
\hline & infant food & 20 & 0.03 & $<$ LOD & 0.12 & 0.15 \\
\hline \multirow[t]{7}{*}{ DAS } & all wheat samples & 3.1 & 0.01 & $<$ LOD & $<\mathrm{LOD}$ & 0.25 \\
\hline & wheat flour & 2.6 & 0.01 & $<$ LOD & $<$ LOD & 0.25 \\
\hline & whole wheat flour & n.d. & $<$ LOD & $<$ LOD & $<$ LOD & $<$ LOD \\
\hline & wheat kernels & 1.9 & $<$ LOD & $<$ LOD & $<$ LOD & 0.25 \\
\hline & semolina & n.d. & $<\mathrm{LOD}$ & $<$ LOD & $<$ LOD & $<$ LOD \\
\hline & wheat bran & 22 & 0.05 & $<$ LOD & 0.25 & 0.25 \\
\hline & infant food & n.d. & $<\mathrm{LOD}$ & $<$ LOD & $<$ LOD & $<$ LOD \\
\hline \multirow[t]{7}{*}{ MAS } & all wheat samples & 92 & 0.30 & 0.11 & 0.88 & 5.9 \\
\hline & wheat flour & 92 & 0.11 & 0.06 & 0.19 & 1.6 \\
\hline & whole wheat flour & 100 & 0.55 & 0.51 & 1.3 & 1.4 \\
\hline & wheat kernels & 98 & 0.27 & 0.21 & 0.67 & 0.86 \\
\hline & semolina & 62 & 0.02 & 0.02 & 0.05 & 0.06 \\
\hline & wheat bran & 100 & 1.6 & 0.83 & 4.9 & 5.9 \\
\hline & infant food & 80 & 0.04 & 0.02 & 0.11 & 0.12 \\
\hline \multirow[t]{7}{*}{ NEO } & all wheat samples & 24 & 0.02 & $<$ LOD & 0.11 & 0.40 \\
\hline & wheat flour & 2.6 & $<\mathrm{LOD}$ & $<\mathrm{LOD}$ & $<\mathrm{LOD}$ & 0.17 \\
\hline & whole wheat flour & 9.1 & $<\mathrm{LOD}$ & $<$ LOD & 0.02 & 0.04 \\
\hline & wheat kernels & 40 & 0.03 & $<$ LOD & 0.12 & 0.15 \\
\hline & semolina & n.d. & $<$ LOD & $<$ LOD & $<$ LOD & $<$ LOD \\
\hline & wheat bran & 89 & 0.10 & 0.04 & 0.33 & 0.40 \\
\hline & infant food & n.d. & $<$ LOD & $<$ LOD & $<$ LOD & $<$ LOD \\
\hline \multirow[t]{7}{*}{ DON } & all wheat samples & 100 & 57 & 23 & 162 & 1163 \\
\hline & wheat flour & 100 & 45 & 25 & 110 & 613 \\
\hline & whole wheat flour & 100 & 39 & 13 & 116 & 131 \\
\hline & wheat kernels & 100 & 49 & 27 & 154 & 235 \\
\hline & semolina & 100 & 39 & 17 & 140 & 172 \\
\hline & wheat bran & 100 & 225 & 64 & 839 & 1163 \\
\hline & infant food & 100 & 12 & 9.9 & 22 & 24 \\
\hline \multirow[t]{6}{*}{ 3-acDON } & all wheat samples & 52 & 0.57 & 0.21 & 2.4 & 15 \\
\hline & wheat flour & 38 & 0.29 & $<$ LOD & 0.77 & 5.2 \\
\hline & whole wheat flour & 64 & 0.44 & 0.21 & 1.5 & 1.8 \\
\hline & wheat kernels & 68 & 0.68 & 0.47 & 2.7 & 3.8 \\
\hline & semolina & 15 & 0.05 & $<$ LOD & 0.31 & 0.47 \\
\hline & wheat bran & 67 & 2.2 & 0.21 & 10 & 15 \\
\hline
\end{tabular}




\begin{tabular}{|c|c|c|c|c|c|c|}
\hline & infant food & 20 & 0.30 & $<$ LOD & 1.2 & 1.5 \\
\hline \multirow[t]{7}{*}{ 15-acDON } & all wheat samples & 72 & 0.90 & 0.17 & 3.5 & 26 \\
\hline & wheat flour & 85 & 0.42 & 0.11 & 0.82 & 8.8 \\
\hline & whole wheat flour & 64 & 0.60 & 0.33 & 1.8 & 2.1 \\
\hline & wheat kernels & 72 & 1.0 & 0.46 & 4.5 & 6.1 \\
\hline & semolina & 46 & 0.10 & $<$ LOD & 0.51 & 0.70 \\
\hline & wheat bran & 78 & 3.8 & 0.96 & 17 & 26 \\
\hline & infant food & 60 & 0.69 & 0.12 & 2.6 & 3.2 \\
\hline \multirow[t]{7}{*}{ NIV } & all wheat samples & 67 & 6.8 & 1.8 & 24 & 96 \\
\hline & wheat flour & 56 & 4.3 & 1.8 & 12 & 77 \\
\hline & whole wheat flour & 91 & 13 & 9.5 & 41 & 62 \\
\hline & wheat kernels & 77 & 5.7 & 1.8 & 19 & 31 \\
\hline & semolina & 31 & 3.4 & $<$ LOD & 17 & 35 \\
\hline & wheat bran & 89 & 23 & 14 & 68 & 96 \\
\hline & infant food & 40 & 2.1 & $<$ LOD & 7.4 & 8.8 \\
\hline \multirow[t]{7}{*}{ FX } & all wheat samples & 5.4 & 0.02 & $<$ LOD & 0.10 & 0.93 \\
\hline & wheat flour & n.d. & $<$ LOD & $<$ LOD & $<$ LOD & $<$ LOD \\
\hline & whole wheat flour & n.d. & $<$ LOD & $<$ LOD & $<$ LOD & $<$ LOD \\
\hline & wheat kernels & 11 & 0.04 & $<$ LOD & 0.18 & 0.93 \\
\hline & semolina & 7.7 & 0.01 & $<$ LOD & 0.07 & 0.18 \\
\hline & wheat bran & n.d. & $<$ LOD & $<$ LOD & $<$ LOD & $<$ LOD \\
\hline & infant food & n.d. & $<$ LOD & $<$ LOD & $<$ LOD & $<$ LOD \\
\hline
\end{tabular}


Table 6. Rates and levels of contamination of different commodities of rye with the most relevant trichothecenes. All samples $(n=61)$, rye flour $(n=15)$, whole rye flour $(n=9)$, rye kernels $(\mathrm{n}=37)$

\begin{tabular}{|c|c|c|c|c|c|c|}
\hline Analyte & Commodity & $\begin{array}{c}\text { Contamination } \\
\text { rate }(\%)\end{array}$ & Mean $\left(\mu \mathrm{g} \mathrm{kg}^{-1}\right)$ & $\begin{array}{l}\text { Median } \\
\left(\mu \mathrm{g} \mathrm{kg}^{-1}\right)\end{array}$ & $\begin{array}{c}\mathbf{9 5}^{\text {th }} \text { percentile } \\
\left(\mu \mathrm{g} \mathrm{kg}^{-1}\right)\end{array}$ & $\begin{array}{c}\text { Maximum } \\
\text { value }\left(\mu \mathrm{g} \mathrm{kg}^{-1}\right)\end{array}$ \\
\hline \multirow[t]{4}{*}{$\mathrm{T}-2$} & all samples & 87 & 0.13 & 0.11 & 0.30 & 0.77 \\
\hline & rye flour & 100 & 0.16 & 0.13 & 0.33 & 0.42 \\
\hline & whole rye flour & 100 & 0.22 & 0.18 & 0.59 & 0.77 \\
\hline & rye kernels & 78 & 0.10 & 0.04 & 0.29 & 0.30 \\
\hline \multirow[t]{4}{*}{ HT-2 } & all samples & 93 & 0.56 & 0.42 & 1.5 & 2.6 \\
\hline & rye flour & 100 & 0.73 & 0.45 & 1.8 & 2.6 \\
\hline & whole rye flour & 100 & 0.76 & 0.54 & 1.8 & 2.2 \\
\hline & rye kernels & 89 & 0.45 & 0.36 & 1.1 & 1.5 \\
\hline \multirow[t]{4}{*}{$\mathrm{T}-2+\mathrm{HT}-2$} & all samples & 95 & 0.69 & 0.53 & 1.8 & 3.1 \\
\hline & rye flour & 100 & 0.89 & 0.57 & 2.1 & 3.1 \\
\hline & whole rye flour & 100 & 1.0 & 0.74 & 2.4 & 3.0 \\
\hline & rye kernels & 92 & 0.55 & 0.51 & 1.4 & 1.8 \\
\hline \multirow[t]{4}{*}{$\mathrm{T}-2$ triol } & all samples & 4.7 & 0.01 & $<$ LOD & $<$ LOD & 0.25 \\
\hline & rye flour & 6.3 & 0.02 & $<$ LOD & 0.06 & 0.25 \\
\hline & whole rye flour & 13 & 0.03 & $<\mathrm{LOD}$ & 0.16 & 0.25 \\
\hline & rye kernels & 2.9 & 0.01 & $<\mathrm{LOD}$ & $<\mathrm{LOD}$ & 0.25 \\
\hline \multirow[t]{4}{*}{$\mathrm{T}-2$ tetraol } & all samples & 79 & 2.3 & 2.0 & 6.4 & 8.1 \\
\hline & rye flour & 88 & 2.5 & 2.3 & 6.3 & 6.4 \\
\hline & whole rye flour & 50 & 2.1 & 0.68 & 6.8 & 7.4 \\
\hline & rye kernels & 81 & 2.3 & 1.9 & 6.4 & 8.1 \\
\hline \multirow[t]{4}{*}{ DAS } & all samples & n.d. & $<$ LOD & $<\mathrm{LOD}$ & $<$ LOD & $<\mathrm{LOD}$ \\
\hline & rye flour & n.d. & $<\mathrm{LOD}$ & $<\mathrm{LOD}$ & $<$ LOD & $<\mathrm{LOD}$ \\
\hline & whole rye flour & n.d. & $<$ LOD & $<\mathrm{LOD}$ & $<$ LOD & $<$ LOD \\
\hline & rye kernels & n.d. & $<\mathrm{LOD}$ & $<\mathrm{LOD}$ & $<$ LOD & $<\mathrm{LOD}$ \\
\hline \multirow[t]{4}{*}{ MAS } & all samples & 87 & 0.05 & 0.02 & 0.15 & 0.31 \\
\hline & rye flour & 94 & 0.05 & 0.03 & 0.14 & 0.20 \\
\hline & whole rye flour & 88 & 0.07 & 0.02 & 0.24 & 0.31 \\
\hline & rye kernels & 84 & 0.04 & 0.02 & 0.13 & 0.18 \\
\hline \multirow[t]{4}{*}{ NEO } & all samples & 15 & 0.01 & $<\mathrm{LOD}$ & 0.04 & 0.10 \\
\hline & rye flour & 19 & 0.01 & $<$ LOD & 0.04 & 0.04 \\
\hline & whole rye flour & 38 & 0.02 & $<\mathrm{LOD}$ & 0.08 & 0.10 \\
\hline & rye kernels & 8.1 & $<$ LOD & $<$ LOD & 0.04 & 0.04 \\
\hline
\end{tabular}




\begin{tabular}{|c|c|c|c|c|c|c|}
\hline \multirow[t]{4}{*}{ DON } & all samples & 100 & 28 & 15 & 92 & 288 \\
\hline & rye flour & 100 & 26 & 23 & 46 & 64 \\
\hline & whole rye flour & 100 & 32 & 6.5 & 105 & 112 \\
\hline & rye kernels & 100 & 28 & 14 & 79 & 288 \\
\hline \multirow[t]{4}{*}{ 3-acDON } & all samples & 59 & 0.39 & 0.21 & 1.6 & 5.0 \\
\hline & rye flour & 63 & 0.19 & 0.21 & 0.54 & 0.63 \\
\hline & whole rye flour & 50 & 0.49 & 0.11 & 2.0 & 2.4 \\
\hline & rye kernels & 59 & 0.45 & 0.21 & 1.6 & 5.0 \\
\hline \multirow[t]{4}{*}{15 -acDON } & all samples & 80 & 0.73 & 0.35 & 2.6 & 8.6 \\
\hline & rye flour & 100 & 0.43 & 0.37 & 0.86 & 0.99 \\
\hline & whole rye flour & 63 & 0.88 & 0.20 & 3.5 & 4.3 \\
\hline & rye kernels & 76 & 0.84 & 0.35 & 2.7 & 8.6 \\
\hline \multirow[t]{4}{*}{ NIV } & all samples & 3.3 & 0.06 & $<$ LOD & $<$ LOD & 1.8 \\
\hline & rye flour & n.d. & $<$ LOD & $<$ LOD & $<$ LOD & $<\mathrm{LOD}$ \\
\hline & whole rye flour & n.d. & $<\mathrm{LOD}$ & $<$ LOD & $<$ LOD & $<$ LOD \\
\hline & rye kernels & 5.4 & 0.10 & $<$ LOD & 0.36 & 1.8 \\
\hline \multirow[t]{4}{*}{ FX } & all samples & 1.6 & 0.01 & $<$ LOD & $<$ LOD & 0.18 \\
\hline & rye flour & n.d. & $<$ LOD & $<$ LOD & $<$ LOD & $<$ LOD \\
\hline & whole rye flour & n.d. & $<$ LOD & $<$ LOD & $<$ LOD & $<$ LOD \\
\hline & rye kernels & 2.7 & $<$ LOD & $<$ LOD & $<$ LOD & 0.18 \\
\hline
\end{tabular}

n.d. $=$ not detectable 
Table 7. Rates and levels of contamination of different commodities of oats with the most relevant trichothecenes: All samples $(n=98)$, fine oat flakes $(n=31)$, oat flakes $(n=23)$, oat kernels ( $\mathrm{n}=19)$, oat bran $(\mathrm{n}=12)$, and oat-containing infant food $(\mathrm{n}=13)$

\begin{tabular}{|c|c|c|c|c|c|c|}
\hline Analyte & Commodity & $\begin{array}{c}\text { Contamination } \\
\text { rate }(\%)\end{array}$ & Mean $\left(\mu \mathrm{g} \mathrm{kg}{ }^{-1}\right)$ & $\begin{array}{l}\text { Median } \\
\left(\mu \mathrm{g} \mathrm{kg}^{-1}\right)\end{array}$ & $\begin{array}{c}95^{\text {th }} \text { percentile } \\
\left(\mu \mathrm{g} \mathrm{kg}^{-1}\right)\end{array}$ & $\begin{array}{c}\text { Maximum } \\
\text { value }\left(\mu \mathrm{g} \mathrm{kg}^{-1}\right)\end{array}$ \\
\hline \multirow[t]{6}{*}{$\mathrm{T}-2$} & all samples & 100 & 4.2 & 2.2 & 15 & 34 \\
\hline & fine oat flakes & 100 & 6.7 & 3.6 & 20 & 34 \\
\hline & oat flakes & 100 & 3.8 & 1.8 & 11 & 17 \\
\hline & oat kernels & 100 & 2.5 & 1.5 & 7.3 & 12 \\
\hline & oat bran & 100 & 4.0 & 3.1 & 9.2 & 11 \\
\hline & infant food & 100 & 1.8 & 1.3 & 4.7 & 5.6 \\
\hline \multirow[t]{6}{*}{ HT-2 } & all samples & 99 & 10 & 6.0 & 35 & 51 \\
\hline & fine oat flakes & 100 & 14 & 8.3 & 44 & 51 \\
\hline & oat flakes & 100 & 9.6 & 5.4 & 24 & 48 \\
\hline & oat kernels & 100 & 7.6 & 4.4 & 18 & 34 \\
\hline & oat bran & 100 & 11 & 8.5 & 25 & 32 \\
\hline & infant food & 92 & 6.1 & 4.7 & 15 & 19 \\
\hline \multirow[t]{6}{*}{$\mathrm{T}-2+\mathrm{HT}-2$} & all samples & 100 & 15 & 8.2 & 50 & 85 \\
\hline & fine oat flakes & 100 & 21 & 12 & 63 & 85 \\
\hline & oat flakes & 100 & 13 & 7.2 & 33 & 65 \\
\hline & oat kernels & 100 & 10 & 6.0 & 25 & 46 \\
\hline & oat bran & 100 & 15 & 12 & 34 & 43 \\
\hline & infant food & 100 & 7.9 & 6.0 & 20 & 23 \\
\hline \multirow[t]{6}{*}{$\mathrm{T}-2$ triol } & all samples & 60 & 0.43 & 0.25 & 1.5 & 2.7 \\
\hline & fine oat flakes & 74 & 0.60 & 0.55 & 1.5 & 2.7 \\
\hline & oat flakes & 52 & 0.39 & 0.25 & 1.4 & 1.5 \\
\hline & oat kernels & 53 & 0.33 & 0.25 & 1.2 & 1.5 \\
\hline & oat bran & 58 & 0.38 & 0.25 & 1.2 & 1.5 \\
\hline & infant food & 54 & 0.26 & 0.25 & 0.85 & 1.3 \\
\hline \multirow[t]{6}{*}{$\mathrm{T}-2$ tetraol } & all samples & 90 & 9.7 & 6.4 & 25 & 85 \\
\hline & fine oat flakes & 94 & 11 & 9.5 & 22 & 34 \\
\hline & oat flakes & 87 & 7.7 & 5.2 & 26 & 27 \\
\hline & oat kernels & 95 & 8.4 & 5.3 & 24 & 24 \\
\hline & oat bran & 100 & 11 & 10 & 26 & 26 \\
\hline & infant food & 69 & 12 & 3.0 & 44 & 85 \\
\hline \multirow[t]{2}{*}{ DAS } & all samples & 60 & 0.05 & 0.04 & 0.17 & 0.38 \\
\hline & fine oat flakes & 71 & 0.08 & 0.04 & 0.19 & 0.38 \\
\hline
\end{tabular}




\begin{tabular}{|c|c|c|c|c|c|c|}
\hline & oat flakes & 65 & 0.04 & 0.04 & 0.12 & 0.17 \\
\hline & oat kernels & 47 & 0.04 & $<$ LOD & 0.17 & 0.25 \\
\hline & oat bran & 75 & 0.04 & 0.04 & 0.08 & 0.12 \\
\hline & infant food & 31 & 0.03 & $<$ LOD & 0.12 & 0.25 \\
\hline MAS & all samples & 95 & 0.09 & 0.07 & 0.23 & 0.66 \\
\hline & fine oat flakes & 97 & 0.59 & 0.28 & 1.9 & 2.7 \\
\hline & oat flakes & 91 & 0.06 & 0.06 & 0.12 & 0.18 \\
\hline & oat kernels & 89 & 0.09 & 0.05 & 0.25 & 0.27 \\
\hline & oat bran & 100 & 0.08 & 0.06 & 0.16 & 0.17 \\
\hline & infant food & 92 & 0.07 & 0.06 & 0.20 & 0.21 \\
\hline NEO & all samples & 92 & 0.37 & 0.22 & 1.4 & 2.7 \\
\hline & fine oat flakes & 97 & 0.59 & 0.28 & 1.9 & 2.7 \\
\hline & oat flakes & 96 & 0.33 & 0.14 & 1.1 & 1.4 \\
\hline & oat kernels & 79 & 0.22 & 0.13 & 0.64 & 0.9 \\
\hline & oat bran & 100 & 0.30 & 0.26 & 0.62 & 0.81 \\
\hline & infant food & 85 & 0.16 & 0.09 & 0.47 & 0.51 \\
\hline DON & all samples & 74 & 2.8 & 0.53 & 11 & 55 \\
\hline & fine oat flakes & 87 & 4.3 & 1.2 & 18 & 55 \\
\hline & oat flakes & 70 & 2.6 & 0.30 & 8.9 & 39 \\
\hline & oat kernels & 84 & 2.9 & 1.1 & 11 & 30 \\
\hline & oat bran & 58 & 0.67 & 0.18 & 2.6 & 4.2 \\
\hline & infant food & 54 & 1.1 & 0.17 & 4.7 & 6.5 \\
\hline 3-acDON & all samples & 28 & 0.43 & $<$ LOD & 2.1 & 8.2 \\
\hline & fine oat flakes & 48 & 0.97 & $<\mathrm{LOD}$ & 5.8 & 8.2 \\
\hline & oat flakes & 13 & 0.27 & $<\mathrm{LOD}$ & 1.9 & 3.6 \\
\hline & oat kernels & 16 & 0.19 & $<$ LOD & 1.4 & 1.9 \\
\hline & oat bran & 25 & 0.12 & $<$ LOD & 0.58 & 0.75 \\
\hline & infant food & 23 & 0.09 & $<$ LOD & 0.44 & 0.78 \\
\hline 15 -acDON & all samples & 28 & 0.11 & $<\mathrm{LOD}$ & 0.63 & 1.4 \\
\hline & fine oat flakes & 32 & 0.13 & $<$ LOD & 0.77 & 1.3 \\
\hline & oat flakes & 8.7 & 0.03 & $<$ LOD & 0.04 & 0.58 \\
\hline & oat kernels & 42 & 0.13 & $<$ LOD & 0.62 & 0.75 \\
\hline & oat bran & 25 & 0.08 & $<$ LOD & 0.35 & 0.38 \\
\hline & infant food & 31 & 0.20 & $<$ LOD & 0.88 & 1.4 \\
\hline NIV & all samples & 24 & 0.96 & $<$ LOD & 6.1 & 17 \\
\hline & fine oat flakes & 39 & 2.0 & $<$ LOD & 7.7 & 17 \\
\hline & oat flakes & 17 & 0.31 & $<$ LOD & 1.8 & 1.8 \\
\hline & oat kernels & 26 & 1.1 & $<$ LOD & 6.4 & 8.7 \\
\hline
\end{tabular}


oat bran 17

infant food $\quad 7.7$

all samples

fine oat flakes

oat flakes

oat kernels

oat bran

infant food

0.30
0.14
0.02
0.01
0.04
0.01
$<$ LOD
0.01

$<$ LOD

$<$ LOD

$<$ LOD

$<$ LOD

$<$ LOD

$<$ LOD

$<$ LOD

$<$ LOD
1.8

0.72

0.18

0.09

0.41

0.02

$<$ LOD

0.07
1.8

1.8

0.53

0.18

0.53

0.18

$<$ LOD

0.18

n.d. $=$ not detectable 
Table 8. Estimated intake of DON, NIV and T-2/HT-2 by average consumption of selected food commodities by two- to five-year-old children" and nine-month-old infants ${ }^{* *}$

\begin{tabular}{|c|c|c|c|c|c|c|c|}
\hline \multirow{3}{*}{ Commodity } & \multirow{3}{*}{$\begin{array}{c}\text { Average } \\
\text { consumption } \\
\text { (g/day) }\end{array}$} & \multicolumn{6}{|c|}{ Estimated toxin intake (ng/day) [\% TDI] } \\
\hline & & \multicolumn{2}{|c|}{ DON } & \multicolumn{2}{|c|}{ NIV } & \multicolumn{2}{|c|}{ T-2/HT-2 } \\
\hline & & mean case & bad case & mean case & bad case & mean case & bad case \\
\hline Wheat flour & $65.2^{*}$ & $1630[10]$ & $7172[44]$ & $117[1.0]$ & $782[6.9]$ & $22[2.3]$ & $72[7.4]$ \\
\hline Rye flour & $12.3^{*}$ & $283[1.8]$ & $566[3.5]$ & $0[0]$ & $0[0]$ & $7.0[0.72]$ & $26[2.7]$ \\
\hline Fine oat flakes & $3.1^{*}$ & $3.7[0.02]$ & $56[0.35]$ & $0[0]$ & $24[0.21]$ & $37[3.8]$ & 195 [20] \\
\hline Oat-containing infant food & $30.1^{* *}$ & $5.1[0.06]$ & $141[1.6]$ & $0[0]$ & $22[0.35]$ & $181[34]$ & 602 [112] \\
\hline
\end{tabular}

${ }^{*}$ Banasiak et al. $2005{ }^{* * *}$ Kersting et al. 1998 


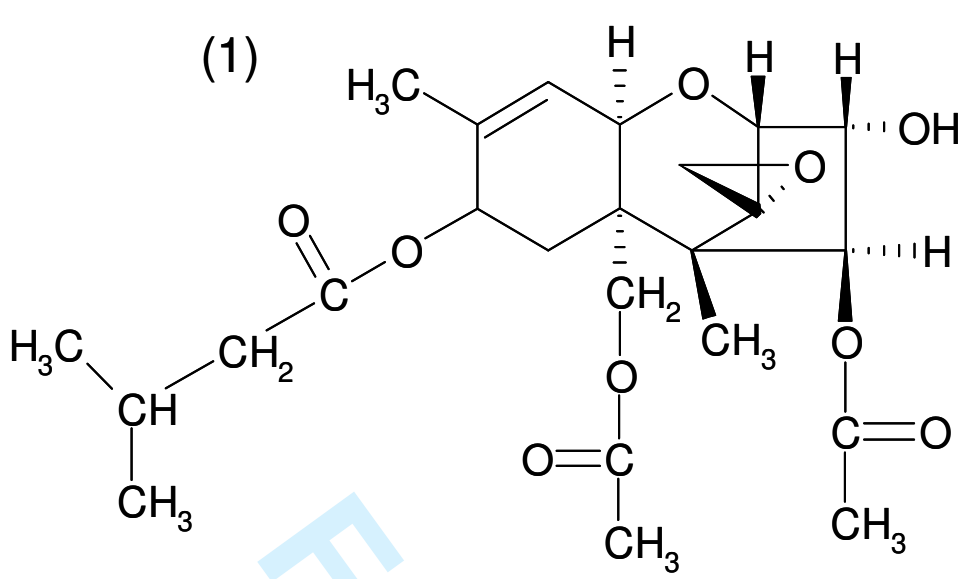

(2)

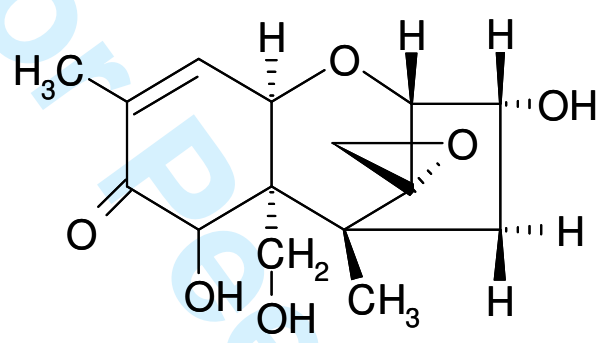

(3)<smiles></smiles>

Figure 1. Examples of different structures of trichothecenes; (1) type A: T-2 toxin; (2) type B: DON; (3) type D: satratoxin G (Ueno 1983a) 


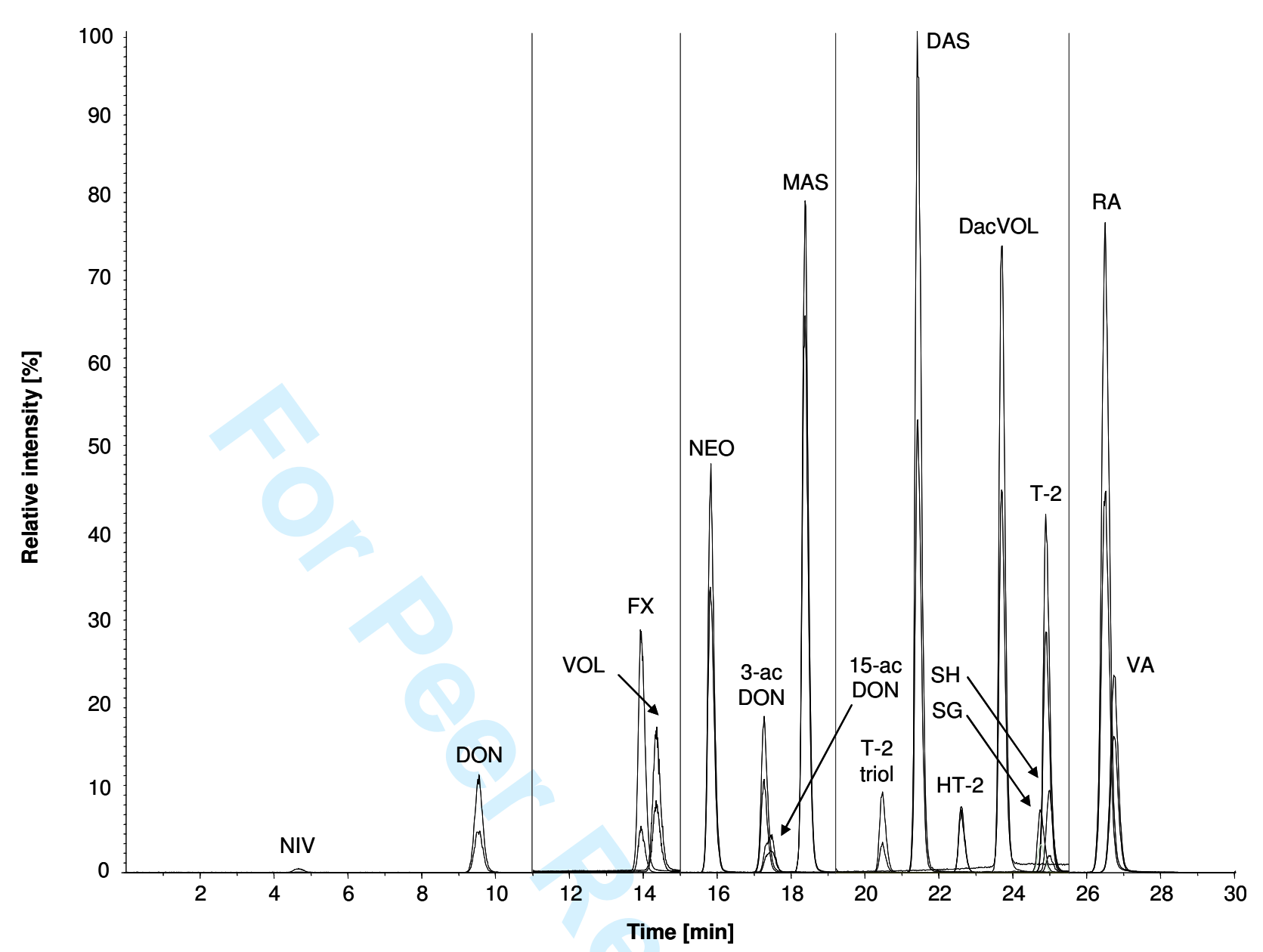

Figure 2. LC-MS/MS chromatogram (separated in five periods) of a multi-trichothecene standard $\left(10 \mathrm{ng} \mathrm{ml}^{-1}\right)$ with two mass transitions per toxin (quantifier and qualifier) 

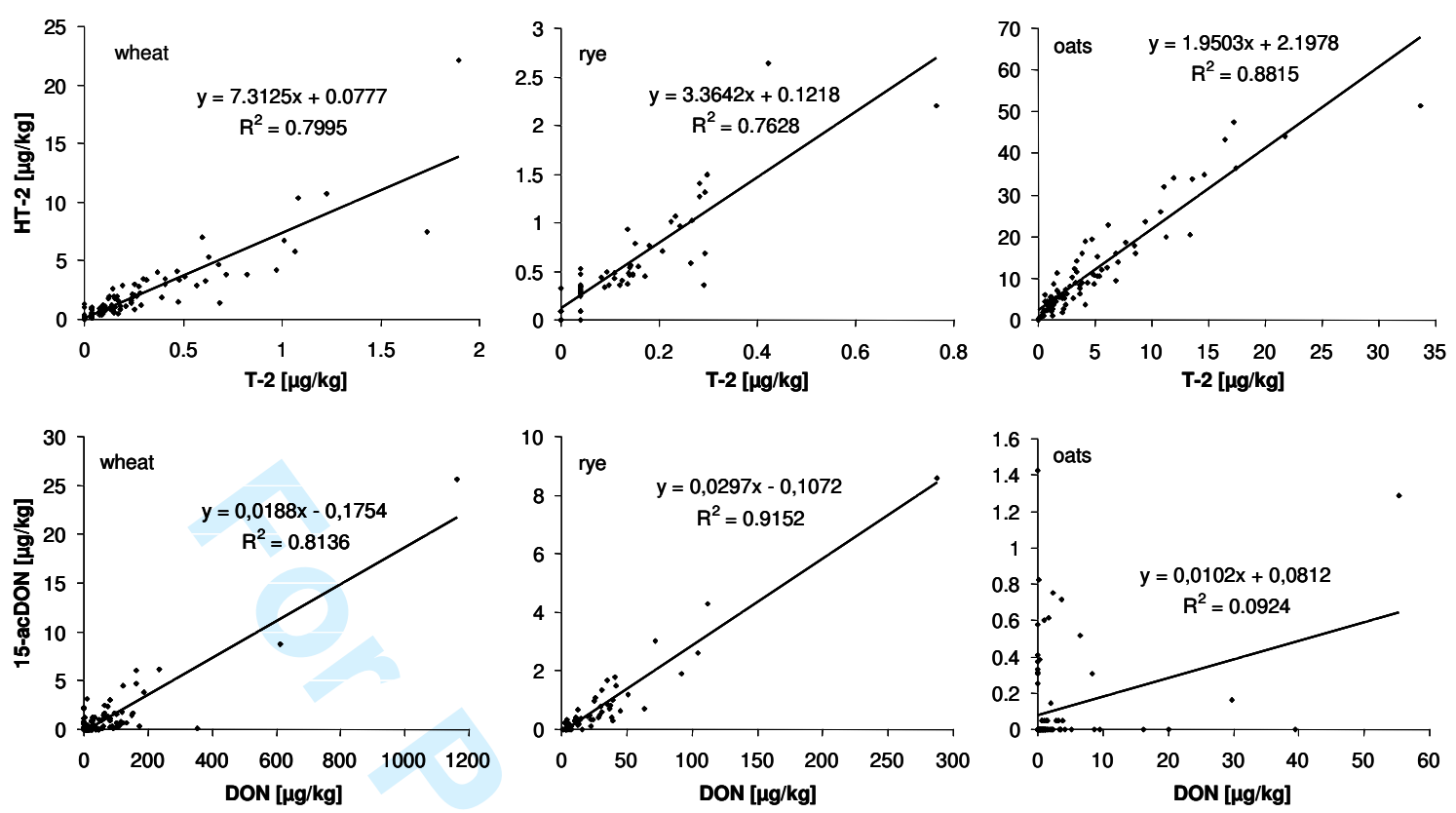

Figure 3. Correlation between T-2 and HT-2 levels (above) and DON and 15-acDON levels (below) in wheat samples $(n=130)$, rye samples $(n=61)$, and oat samples $(n=98)$ 

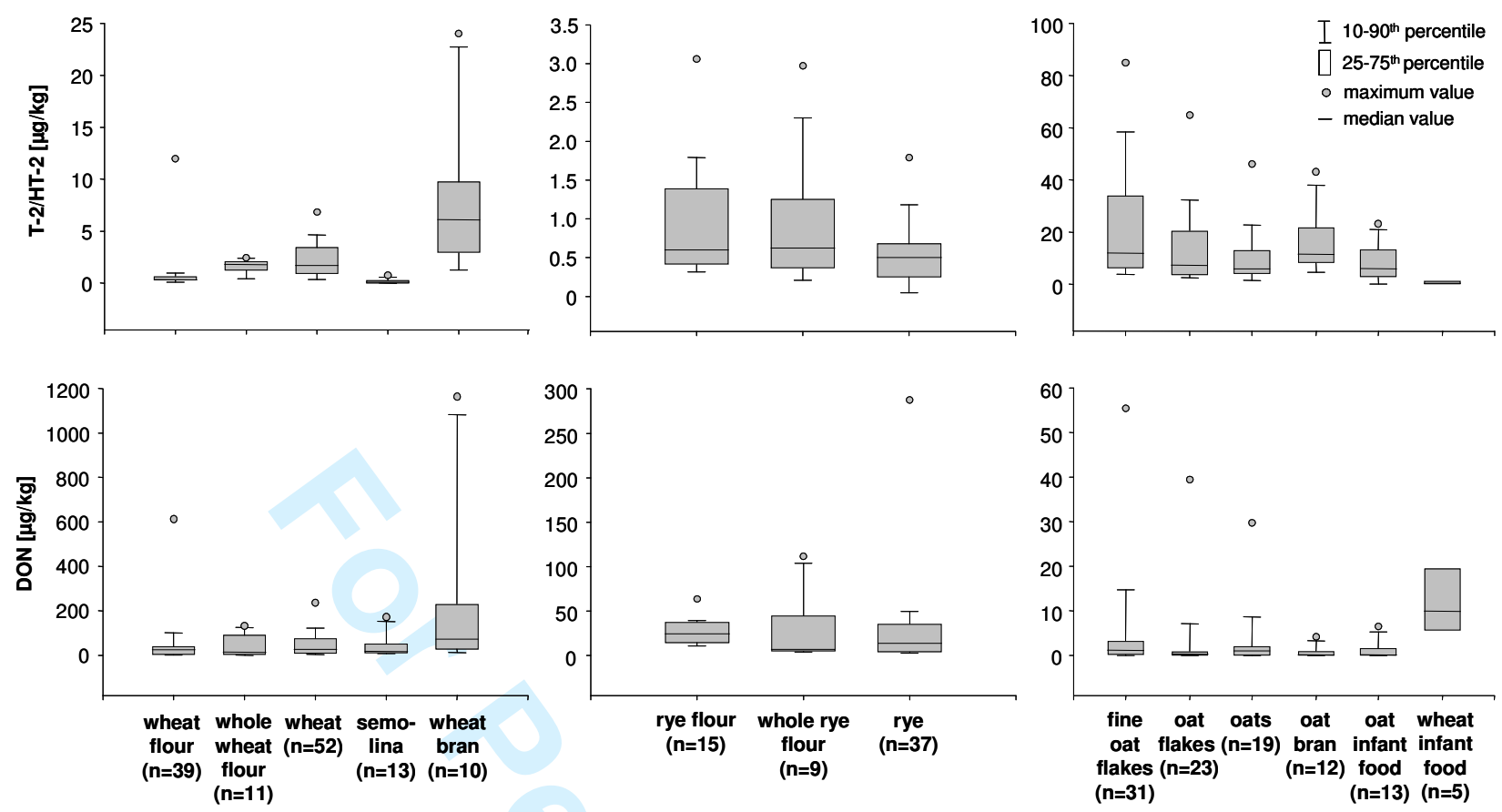

Figure 4. Comparison of contamination levels of T-2/HT-2 and DON in different food commodities of wheat, rye and oats 